\title{
Inhibition of DNA-PK by gefitinib causes synergism between gefitinib and cisplatin in NSCLC
}

\author{
CHI PAN ${ }^{1,2^{*}}$, HUIJIE DUAN ${ }^{2,3^{*}}$, YINAN WU ${ }^{2}$, CHUNPENG ZHU $^{4}$, CHENGHAO YI $^{5}$, YIN DUAN $^{6}$, \\ DEMIN LU ${ }^{3}$, CHENG GUO $^{2}$, DEQI WU ${ }^{7}$, YANYAN WANG ${ }^{1}$, XIANHUA FU $^{3}$, JING XU $^{2,8}$, YIDING CHEN $^{1,2}$, \\ MENG LUO $^{2}$, WEI TIAN ${ }^{1}$, TAO PAN $^{1}$, WENHONG XU ${ }^{2,8}$, SUZHAN ZHANG $^{2,9}$ and JIANJIN HUANG ${ }^{3}$ \\ ${ }^{1}$ Department of Breast Surgery; ${ }^{2}$ Cancer Institute (National Ministry of Education Key Laboratory of \\ Cancer Prevention and Intervention); Departments of ${ }^{3}$ Medical Oncology and ${ }^{4}$ Gastroenterology, \\ The Second Affiliated Hospital, Zhejiang University School of Medicine, Hangzhou, Zhejiang 310009; \\ ${ }^{5}$ Department of Breast Surgery, The Second Affiliated Hospital, Nanchang University, Nanchang, Jiangxi 330006; \\ ${ }^{6}$ Department of Breast Surgery, The Zhejiang Provincial Hospital of Traditional Chinese Medicine; \\ ${ }^{7}$ Department of Gastrointestinal Thyroid and Breast Surgery, The Shulan (Hangzhou) Hospital; \\ ${ }^{8}$ Department of Radiation Oncology; ${ }^{9}$ Research Center for Air Pollution and Health, The Second Affiliated Hospital, \\ Zhejiang University School of Medicine, Hangzhou, Zhejiang 310009, P.R. China
}

Received July 28, 2019; Accepted May 4, 2020

DOI: $10.3892 / \mathrm{ijo} .2020 .5103$

\begin{abstract}
Lung cancer has the highest incidence and mortality rates among the malignant tumor types worldwide. Platinum-based chemotherapy is the main treatment for advanced non-small-cell lung cancer (NSCLC), and epidermal growth factor receptor-tyrosine kinase inhibitors (EGFR-TKIs) have greatly improved the survival of patients with EGFR-sensitive mutations. However, there is no standard therapy for treating patients who are EGFR-TKI resistant. Combining EGFR-TKIs and platinum-based chemotherapy is the most popular strategy in the clinical practice. However, the synergistic mechanism between EGFR-TKIs and platinum remains unknown. Therefore, the aim of the present study was to determine the synergistic mechanism of gefitinib (an EGFR-TKI) and cisplatin (a main platinum-based drug). MTT assay, apoptosis analysis, tumorsphere formation and
\end{abstract}

Correspondence to: Dr Jianjin Huang, Department of Medical Oncology, The Second Affiliated Hospital, Zhejiang University School of Medicine, 88 Jiefang Road, Hangzhou, Zhejiang 310009, P.R. China

E-mail: hhjj@zju.edu.cn

Dr Suzhan Zhang, Cancer Institute (National Ministry of Education Key Laboratory of Cancer Prevention and Intervention), The Second Affiliated Hospital, Zhejiang University School of Medicine, 88 Jiefang Road, Hangzhou, Zhejiang 310009, P.R. China

E-mail: zrsj@zju.edu.cn

*Contributed equally

Key words: gefitinib, cisplatin, DNA-dependent protein kinase, synergism, non-small-cell lung cancer an orthotropic xenograft mouse model were used to examine the combination effects of gefitinib and cisplatin on NSCLC. Co-immunoprecipitation and immunofluorescence were used to identify the underlying mechanism. It was found that gefitinib could selectively inhibit EGFR from entering the nucleus, decrease DNA-PK activity and enhance the cytotoxicity of cisplatin on NSCLC. Collectively, the results suggested that inhibition of DNA-dependent protein kinase by gefitinib may be due to the synergistic mechanism between gefitinib and cisplatin. Thus, the present study provides a novel insight into potential biomarkers for the selection of combination therapy of gefitinib and cisplatin.

\section{Introduction}

Lung cancer is the most common malignant tumor, and its incidence and mortality rates are $\sim 11.6$ and $\sim 18.4 \%$ worldwide, which are continuously rising (1). Lung cancer is insidious and difficult to detect in the early stage, and this disease seriously threatens patient health. The treatment strategy for advanced non-small-cell lung cancer (NSCLC) is mainly based on platinum-based chemotherapy $(2,3)$. However, the curative effect of chemotherapy is limited, and the effective rate has reached a plateau that has been difficult to overcome (4). Chemotherapy drugs are highly toxic and can cause serious side effects, and thus are intolerable to patients (4). In the past decade, epidermal growth factor receptor-tyrosine kinase inhibitors (EGFR-TKIs) have influenced the therapeutic strategies for advanced NSCLC, providing notable survival benefits to patients with EGFR-sensitive mutations, including exon 19 deletion and exon 21 L858R mutation $(5,6)$. However, numerous patients cannot benefit or continue to benefit from EGFR-TKI monotherapy due to primary and secondary drug resistance (7).

Currently, there is no standard strategy available for treating patients who are EGFR-TKI resistant. The common 
therapeutic strategies usually include: Platinum-based chemotherapy, high-dose EGFR-TKIs, platinum-based chemotherapy combined with EGFR-TKIs, new targeted drugs monotherapy (7), such as AZD929 (EGFR-TKI inhibitor) (8), afatinib (dual EGFR and human EGFR 2 inhibitor) (9), vandetanib (dual EGFR and vascular EGFR inhibitor) (10) and crizotinib (for patients with anaplastic lymphoma kinase mutations) (11). Furthermore, common therapeutic strategies involve new agents combined with EGFR-TKI, such as apatinib (12), AXL receptor tyrosine kinase degradation (13) and Crizotinib (14). However, most of these agents are still in clinical trials, and the combination therapy of EGFR-TKIs and platinum-based chemotherapy is the preferred choice for most patients. Previous studies have reported that such combination therapy could improve the overall survival and progression-free survival of patients (15-18). The synergistic mechanism between EGFR-TKIs and platinum remains unknown, and no biomarkers are currently available to predict the benefit of the combination therapy. If the phenotype of sensitive combinations could be determined, patients may benefit from the combination strategy. However, it is not possible to accurately determine the selection of appropriate patients without understanding the mechanisms of interactions between EGFR-TKIs and chemotherapy agents. Thus, biomarkers could only be identified when the synergistic mechanisms between EGFR-TKIs and platinum-based chemotherapy are understood.

The present study investigated the interaction between gefitinib (an EGFR-TKI) and cisplatin (a main platinum-based drug) to identify the mechanisms of their synergistic effects in NSCLC. Gefitinib was developed to target $\operatorname{EGFR}(19,20)$, and cisplatin is a cytotoxic drug that directly targets DNA and promotes the DNA double helix to form hinges that limit DNA unwinding, inhibit DNA replication and induce tumor necrosis $(21,22)$. Previous studies have revealed that some of the agents affecting cisplatin sensitivity are mainly DNA repair proteins $(23,24)$, such as DNA-dependent protein kinase (DNA-PK) (25), ERCC excision repair 1, endonuclease non-catalytic subunit (ERCC1) (26) and BRCA1 DNA repair associated (BRCA1) (27). DNA-PK is the pivotal kinase protein involved in non-homologous end joining pathways of DNA double-strand-break repair (25). Previous studies have also reported that intracellular EGFR could interact with DNA-PK $(28,29)$. Moreover, EGFR in the cytoplasm can enter nucleus and regulate the transcription of DNA repair-related genes $(30,31)$, assisting in the repair of DNA breaks $(29,32)$. The aim of the present study was to determine the synergistic mechanism of gefitinib and cisplatin.

\section{Materials and methods}

Chemicals and antibodies. The selective EGFR-TKI gefitinib (GD760; Iressa), kindly provided by AstraZeneca PLC, was dissolved in pure DMSO to a working concentration of 20 mM. Cisplatin, MTT, Nucleopriein Extraction kit and AnnexinV-FITC Apoptosis Detection kit were obtained from Sigma-Aldrich (Merck KGaA). The caspase-3 Activity Assay kit was purchased from Beyotime Institute of Biotechnology. The DNA-PK inhibitor NU7441 (KU-57788) was purchased from Selleck Chemicals. Antibodies against Akt (cat. no. 4691), phosphorylated (p)-Akt (Thr308; cat. no. 13038), ERK1/2 (cat. no. 9102), p-ERK1/2 (Thr202/Tyr204; cat. no. 4370), PTEN (cat. no. 9188), BRCA1 (cat. no. 9010), p-BRCA1 (Ser1524; cat. no. 9009), DNA-PK (cat. no. 38168), p-DNA-PK (Ser2056; cat. no. 68716), EGFR (cat. no. 4267), p-EGFR (Tyr1068; cat. no. 3777), ERCC1 (cat. no. 12345), caspase-3 (cat. no. 9662), Cleaved caspase-3 (cat. no. 9661), $\beta$-actin (cat. no. 4970) and Lamin B1 (cat. no. 13435), purchased from Cell Signaling Technology, Inc., which were diluted to 1:1,000 for western blot analysis and Co-immunoprecipitation (Co-IP) analysis.

Cell lines. The human NSCLC cell lines were used: A549, H1299 and H1975 (Cell Bank of Chinese Academy of Sciences) with different EGFR and Kirsten rat sarcoma 2 viral oncogene homolog (K-Ras) gene statuses [exons 18-21 of the $E G F R$ gene and exons 2-3 of the $K$-Ras gene were sequenced, the A549 cell line harbors the pathogenic mutation of $K$-Ras (exon 2 G12S), the H1975 cell line carries EGFR L858 and T790M and the EGFR and K-Ras of the H1299 cell line are all wild-type]. Cell lines were maintained in RPMI-1640 media (Gibco; Thermo Fisher Scientific, Inc.) supplemented with $10 \%$ fetal calf serum (Gibco; Thermo Fisher Scientific, Inc.) and were cultured at $37^{\circ} \mathrm{C}$ in a $5 \% \mathrm{CO}_{2}$ atmosphere in a humidified incubator.

Sequencing of EGFR and K-ras genes. The exons encoding the intracellular domain of EGFR and $K$-ras were amplified by PCR [the source DNA was genomic DNA of cell lines, the DNA polymerase was pfu DNA polymerase (Promega Corproation); thermocycling conditions were as follows: Initial denaturation at $95^{\circ} \mathrm{C}$ for $1.5 \mathrm{~min}$, followed by 30 cycles at $95^{\circ} \mathrm{C}$ for $40 \mathrm{sec}$, $52-60^{\circ} \mathrm{C}$ for $30 \mathrm{sec}$ and $72^{\circ} \mathrm{C}$ for $2 \mathrm{~min}$, with a final extension step at $72^{\circ} \mathrm{C}$ for $5 \mathrm{~min}$, and help at $4^{\circ} \mathrm{C}$ ] and sequenced by bidirectional sequence. The EGFR exon 18-21 and K-ras exon 2-3 were amplified from H1299, A549 and H1975 cDNA, and the PCR products were isolated and sequenced. The primer sequences are listed in Table I. Tests were performed at least twice for every sample.

Cell apoptosis analysis. H1299, A549 and H1975 cells were seeded in 6 -well plates at $2 \times 10^{5}$ cells per well and incubated at $37^{\circ} \mathrm{C}$ overnight. After treatment with $10 \mu \mathrm{M}$ gefitinib or $15 \mu \mathrm{M}$ cisplatin at $37^{\circ} \mathrm{C}$ for $48 \mathrm{~h}$, the cells were collected and assessed using an Annexin V-FITC Apoptosis Detection kit (Sigma-Aldrich; Merck KGaA), according to the manufacturer's instructions. Then, cells were detected by a BD FACSCalibur Flow Cytometer (BD Biosciences) and analyzed with FlowJo software (Ver.10 for windows; BD Biosciences). The activation of caspase-3 was detected using the caspase-3 Activity Assay kit (Beyotime Institute of Biotechnology) according to the manufacturer's instructions. Cells were washed twice in PBS and lysed in Lysis Buffer (containing $1 \mathrm{mM}$ DTT, $1 \mathrm{mM}$ PMSF and protease inhibitor) on ice for 20-60 min. Lysates were centrifuged at 15,000 x g for $1 \mathrm{~min}$ at $4^{\circ} \mathrm{C}$. Appropriate protein extracts $(100-200 \mu \mathrm{g})$ of cell lysates was treated with Reaction Buffer and Caspase-3 Substrate $37^{\circ} \mathrm{C}$ for $4 \mathrm{~h}$. Absorbance was measured at $400 \mathrm{~nm}$ wavelength using a multiwall spectrophotometer (Bio-Rad Laboratories, Inc.). Caspase-3 Activity was expressed as the percentage of agents-treated cells vs. control cells, whose 
Table I. Primers for EGFR (exon 18, 19, 20 and 21) and K-Ras (exon 2 and 3).

\begin{tabular}{lcll}
\hline Gene & Exon & \multicolumn{1}{c}{ Forward $\left(5^{\prime} \rightarrow 3^{\prime}\right)$} & \multicolumn{1}{c}{ Reverse $\left(5^{\prime} \rightarrow 3^{\prime}\right)$} \\
\hline EGFR & 18 & CAAATGAGCTGGCAAGTGCCGTGT & GAGTTTCCCAAACACTCAGTGAAA \\
& 19 & GCAATATCAGCCTTAGGTGCGGCTC & CATAGAAAGTGAACATTTAGGATGTG \\
& 20 & ACTTCACAGCCCTGCGTAAAC & ATGGGACAGGCACTGATTTGT \\
K-Ras & 21 & CTAACGTTCGCCAGCCATAAGTCC & GCTGCGAGCTCACCCAGAATGTCTGG \\
& 2 & CTTAAGCGTCGATGGAGGAG & CCCTGACATACTCCCAAGGA \\
& 3 & TGGGTATGTGGTAGCATCTCA & AATCCCAGCACCACCACTAC \\
\hline
\end{tabular}

EGFR, epidermal growth factor receptor; K-ras, Kirsten rat sarcoma 2 viral oncogene homolog.

activity was considered $0 \%$. The experiments were independently performed three times.

MTT assay. Cells grown to 70-80\% confluence were harvested, seeded in 96-well microtiter plates at 3,000 cells per well and incubated at $37^{\circ} \mathrm{C}$ overnight. Cells were then treated with various concentrations (the specific concentration is listed in the corresponding figures) of gefitinib or cisplatin at $37^{\circ} \mathrm{C}$ for $72 \mathrm{~h}$. When measuring cell viability, $5 \mathrm{mg} / \mathrm{ml}$ MTT was added into the media and cells were cultured at $37^{\circ} \mathrm{C}$ for $4 \mathrm{~h}$. Plate centrifugation was performed in the speed of $1,000 \mathrm{rpm}$ for 15 min under normal temperature. Then, the supernatant was removed by pipette and the formazan crystals were dissolved in $200 \mathrm{ml} \mathrm{DMSO}$ for $15 \mathrm{~min}$. Absorbance was measured at $570 \mathrm{~nm}$ wavelength using a multiwall spectrophotometer (Bio-Rad Laboratories, Inc.). Cell viability was expressed as the percentage of surviving agents-treated cells vs. control cells whose viability was considered $100 \%$. The combination index (CI) values of the two drugs were calculated using the Chou-Talalay median method as previously described (33). To assess the interaction between cisplatin and gefitinib on cell lines, cells were pretreated with $15 \mu \mathrm{M}$ cisplatin at $37^{\circ} \mathrm{C}$ for $72 \mathrm{~h}$ before gefitinib was administered or pretreated with $10 \mu \mathrm{M}$ gefitinib before cisplatin was administered. To examine whether gefitinib could inhibit DNA-PK activation, cells were treated with $20 \mathrm{nM}$ NU7441 (DNA-PK specific inhibitor), $10 \mu \mathrm{M}$ gefitinib and a combination of cisplatin (the specific concentration is listed in the corresponding figures) at $37^{\circ} \mathrm{C}$ for $72 \mathrm{~h}$. These experiments were independently performed in triplicate.

Western blot analysis. Whole cell protein and nuclear protein were obtained by respectively treating cells with RIPA buffer (Beyotime Institute of Biotechnology) and Nucleopriein Extraction kit (Sigma-Aldrich; Merck KGaA), containing protease inhibitor cocktail and phosphatase inhibitor (Bimake. com) for $30 \mathrm{~min}$ on ice. Proteins were then determined using a bicinchoninic acid assay kit (Thermo Fisher Scientific, Inc.). Appropriate protein extracts (40-60 $\mu \mathrm{g}$ ) of cell lysates were loaded per lane and fractionated through SDS-PAGE (5\% blocking gel at $4^{\circ} \mathrm{C}$ for $30 \mathrm{~min} ; 8-12 \%$ separating gel) and were electro-transferred to PVDF membranes (EMD Millipore). The membranes were immersed in the blocking reagent (5\% non-fat milk) and shaken slowly on a shaker at room temperature for $1 \mathrm{~h}$. Membranes were then probed with various primary antibodies (the aforementioned antibodies) and horseradish peroxidase-conjugated secondary antibodies (cat. no. FD-GAR007; 1:5,000; Fude Biological Technology Co., Ltd.), and were visualized using ECL detection reagents (EMD Millipore). The molecular weights of the immunoreactive proteins were estimated based on the PageRuler Prestained Protein ladder (Fermentas; Thermo Fisher Scientific, Inc.). Experiments were repeated $\geq 3$ times.

Tumorsphere formation and growth assays. After adding $200 \mu \mathrm{l}$ Matrigel (BD Bioscience) per well in 24-well plate (Corning, Inc.) at $37^{\circ} \mathrm{C}$ in an incubator for $30 \mathrm{~min}$, cells $(100 \mu \mathrm{l}$ per well) were seeded onto the $24-w e l l$ plate at 1,000 cells $/ \mathrm{ml}$ and cultured in the tumorsphere medium: RPMI-1640 medium supplemented with Matrigel at $10 \%$ volume ratio. NSCLC cells were treated with low-concentration $6 \mu \mathrm{M}$ gefitinib and high-concentration $20 \mu \mathrm{M}$ cisplatin at $37^{\circ} \mathrm{C}$ in an incubator according to the following treatment regimens: i) Control group (Control), RPMI-1640 media without drug for 18 days; ii) Cisplatin monotherapy group (cisplatin), RPMI-1640 media without drug for 12 days and $20 \mu \mathrm{M}$ cisplatin for 6 days; iii) Gefitinib combined with cisplatin group (gefitinib + cisplatin), RPMI-1640 media without drug-treated tumorspheres for 12 days and $20 \mu \mathrm{M}$ cisplatin combined with $6 \mu \mathrm{M}$ gefitinib for 6 days; and iv) Gefitinib pretreatment group (gefitinib $\rightarrow$ cisplatin), RPMI-1640 media without drugs for 6 days, $6 \mu \mathrm{M}$ gefitinib for 6 days and $20 \mu \mathrm{M}$ cisplatin for 6 days. The volumes of tumorspheres were measured using a light microscope rule (magnification, $\mathrm{x} 20$ ) once every 6 days and were calculated [Volume $\left(\mathrm{mm}^{3}\right)=\pi \mathrm{x}$ length $\mathrm{x}$ width ${ }^{2} / 6$ ]. The experiments were independently performed in triplicate.

Co-IP assays. Cells were washed twice in PBS and lysed in a IP buffer (containing $1 \mathrm{mM}$ DTT, $100 \mathrm{mmol} / \mathrm{l} \mathrm{NaCl}$ and $1 \mathrm{mM}$ $\mathrm{MgCl}_{2}$ ) and protease inhibitor cocktails (Bimake.com). Lysates were centrifuged at $12,000 \mathrm{x}$ g for $10 \mathrm{~min}$ at $4^{\circ} \mathrm{C}$. The total cell lysates were used for IP with primary antibodies (anti-EGFR or anti-DNA-PK $\mathrm{CS}_{\mathrm{C}}$ ) on protein $\mathrm{A}+\mathrm{G}$ mix beads (Thermo Fisher Scientific, Inc.) at $4^{\circ} \mathrm{C}$ overnight The immunoprecipitates were collected and prepared for western blot analysis, which was performed as aforementioned. In total, $100 \mu \mathrm{l}$ cell lysates were used as the input control for western blot analysis.

Orthotopic xenograft assay. A total of 16 female athymic mice (BALB/c $\mathrm{c}^{\mathrm{nu} / \mathrm{nu}}$; age, 5 weeks; weight, 15-18 g) were ordered 
from the Experimental Animal Center of Zhejiang Chinese Medical University. Mice were housed in cages with wood chip beddings in a temperature-controlled room $(68-72 \mathrm{uF}$; $24^{\circ} \mathrm{C}$ ) with a $12 \mathrm{~h}$ light-dark cycle and $45-55 \%$ relative humidity and were permitted free access to food and drinking water. All of the animal experiments described in this study were approved by the Institutional Animal Care and USE Committee (IACUC) at Zhejiang University. All animals were maintained in accordance with the IACUC guideline.

These mice were randomized into four groups as follows: i) Control group (Control), intraperitoneal injection of normal saline $0.01 \mathrm{ml} / \mathrm{g}$ with DMSO; ii) Gefitinib alone group (gefitinib alone), intraperitoneal injection of $35 \mathrm{mg} / \mathrm{kg}$ gefitinib; iii) Cisplatin alone group (cisplatin alone), intraperitoneal injection of $5 \mathrm{mg} / \mathrm{kg}$ cisplatin; and iv) Combination of gefitinib and cisplatin group (gefitinib + cisplatin): Intraperitoneal injection of $35 \mathrm{mg} / \mathrm{kg}$ gefitinib and $5 \mathrm{mg} / \mathrm{kg}$ cisplatin. Mice were injected with $2 \times 10^{6} \mathrm{H} 1299$, A549 and H1975 cells suspension in $100 \mathrm{ml}$ RPMI-1640 medium containing $50 \%$ Matrigel (BD Bioscience) subcutaneously into the right flank. The mice were randomly assigned to experimental and control groups (4 mice/group) when the tumors reached the size of $50 \mathrm{~mm}^{3}$. The mice were fasted overnight and then administered $35 \mathrm{mg} / \mathrm{kg}$ gefitinib and/or $5 \mathrm{mg} / \mathrm{kg}$ cisplatin or $0.9 \%$ physiological saline (vehicle) by intraperitoneal injection once every 3 days for 15 day. The treatment was started on day 7 and stopped on day 22. Tumors were measured using calipers once every 3 days, and the tumor volumes were calculated [Volume $\left(\mathrm{mm}^{3}\right)=\pi \mathrm{x}$ length $\mathrm{x}$ width ${ }^{2} / 6$ ]. According to the Animal Ethics of IACUC at Zhejiang University, the experiment ended when the largest tumor volume approached $2,000 \mathrm{~mm}^{3}$. The mice were sacrificed by cervical dislocation under deep inhalation anesthesia with $2 \%$ isoflurane at the end of the experiment. At the end of study, tumor tissues were harvested, fixed in $10 \%$ formalin at room temperature for $24 \mathrm{~h}$ and then embedded in paraffin. Tumor sections (thickness, 2-3 $\mu \mathrm{m}$ ) were subjected to standard hematoxylin for $10 \mathrm{~min}$ and eosin for $10 \mathrm{sec}$ at room temperature (H\&E) staining using a light microscope (magnification, x100). The experiment was conducted in triplicate.

Immunofluorescence. After treatment with $10 \mu \mathrm{M}$ gefitinib or $15 \mu \mathrm{M}$ cisplatin at $37^{\circ} \mathrm{C}$ for $48 \mathrm{~h}$, cells were fixed in $4 \%$ paraformaldehyde at room temperature for $15 \mathrm{~min}$, incubated in $0.1 \%$ Triton X-100 at room temperature for $10 \mathrm{~min}$ and washed with PBS. Cells were blocked with goat serum (Gibco; Thermo Fisher Scientific, Inc.) at room temperature for $60 \mathrm{~min}$, stained with primary EGFR antibody or DNA-PK antibody (aforementioned antibodies; $1: 250)$ at $4^{\circ} \mathrm{C}$ overnight and secondary antibodies (cat. no. 102-095-003; Jackson ImmunoResearch Laboratories; $1: 50$ ) at $37^{\circ} \mathrm{C}$ for $60 \mathrm{~min}$. Then, cells were counterstained by DAPI (Sigma-Aldrich; Merck KGaA) at room temperature for $15 \mathrm{~min}$. The images were acquired by confocal laser-scanning microscopy (magnification, x200; Zeiss LSM710; Zeiss AG).

Statistical analysis. Data are presented as the mean \pm standard error of mean obtained from $\geq 3$ experiments. The two-tailed Student's t-tests were used for analyzing statistical differences between two groups and one-way ANOVA was used with a post hoc Tukey for multiple comparisons when comparing $>2$ groups using SPSS software (Ver.22 for Mac; SPSS, Inc.). Graphs were generated using GraphPad Prism software (Ver.6 for Mac; GraphPad Software, Inc.). $\mathrm{P}<0.05$ was considered to indicate a statistically significant difference.

\section{Results}

Evaluation of the antiproliferative effect of gefitinib and cisplatin on NSCLC cell lines with different EGFR and K-ras mutations. EGFR and K-ras genes were sequenced to identify that H1299 cells are wild-type, that A549 cells carry K-ras G12S mutation and that H1975 cells carry EGFR L858R and T790M mutations (Table II).

A549, H1299 and H1975 cells were treated with $10 \mu \mathrm{M}$ gefitinib and $15 \mu \mathrm{M}$ cisplatin for $48 \mathrm{~h}$ to investigate the sensitivity of the three types of NSCLC cells with different EGFR and K-ras mutants. Apoptosis was assessed using Annexin V-FITC/propidium iodide (PI) dual staining by FACSCalibur Flow Cytometer. Apoptosis in the treatment groups was markedly higher compared with the control group of each cell line, and no significant difference in sensitivity of gefitinib and cisplatin was found between the three cell lines (Fig. 1A and B). A MTT assay was performed, and the results suggested that the three cell lines were similarly resistant to gefitinib (The $\mathrm{IC}_{50}$ values of gefitinib in Fig. $1 \mathrm{C}$ are presented in Table II), and the cisplatin $\mathrm{IC}_{50}$ values were also similar among the cell lines (The $\mathrm{IC}_{50}$ values of cisplatin in Fig. 1D are presented in Table II).

Synergistic and antagonistic antiproliferative effects of gefitinib and cisplatin combination. Each cell line was treated with the combination of cisplatin and gefitinib for $72 \mathrm{~h}$ with relatively suitable concentration (Fig. 2A-a, B-a and C-a) based on the $\mathrm{IC}_{50}$ ratio of the two agents to investigate the combined effects of cisplatin and gefitinib in the three types of NSCLC with different EGFR and K-ras genotypes. Cell viability was measured by using the MTT method, and the combination index (CI) values of the two drugs were calculated using the Chou-Talalay median method as previously described (33). A marked decrease in cell viability was observed after cisplatin was combined with gefitinib in H1299 cells (EGFR wild-type; K-ras wild-type; Fig. 2A-a). The CI values of cisplatin and gefitinib at any inhibition rate were $<1$, and the $\mathrm{CI}$ value decreased as the inhibition rate increased (Fig. 2A-b). This finding indicates that the combined effect of cisplatin and gefitinib in H1299 cells was synergistic, and the synergistic effect was stronger as the combination concentration of the two agents was increased.

A decrease in cell viability was observed after combination treatment in A549 cells (EGFR wild-type; K-ras exon-2 G12S mutation; Fig. 2B-a). However, the CI value in A549 cells spanned over one (Fig. 2B-b), suggesting that the combined effect in A549 cells was mixed. For instance, the effect was antagonistic when the drugs were combined at low concentrations but was synergistic as the concentrations increased.

The combined effect in H1975 cells (EGFR exon-21 L858R; exon-20 T790M mutation; K-ras wild-type) was antagonistic. No significant decrease in cell viability was found in the combination treatment group in H1975 cells (Fig. 2C-a). 
Table II. Cytotoxicity of gefitinib or cisplatin and the mutation status of EGFR and $K$-Ras gene in human non-small-cell lung cancer cell lines.

\begin{tabular}{|c|c|c|c|c|c|}
\hline Cell line & Cell type & $E G F R$ gene & K-Ras gene & Gefitinib $\mathrm{IC}_{50}(\mu \mathrm{mol} / \mathrm{l})$ & Cisplatin $\mathrm{IC}_{50}(\mu \mathrm{mol} / \mathrm{l})$ \\
\hline A549 & Adenocarcinoma & WT & G12S exon 2 & $13.2 \pm 2.69$ & $11.9 \pm 2.77$ \\
\hline H1299 & Large cell & WT & WT & $17.5 \pm 4.54$ & $11.6 \pm 1.88$ \\
\hline H1975 & Adenocarcinoma & L858R, T790M & WT & $16.6 \pm 2.38$ & $14.6 \pm 6.45$ \\
\hline
\end{tabular}

Data are presented as the mean $\pm \mathrm{SD}$ of $\mathrm{IC}_{50}$ values for each cell line. WT, wild type; EGFR, epidermal growth factor receptor; K-ras, Kirsten rat sarcoma 2 viral oncogene homolog. Cytotoxicity was determined by MTT assay, IC $_{50}$ values were calculated using GraphPad Prism software.

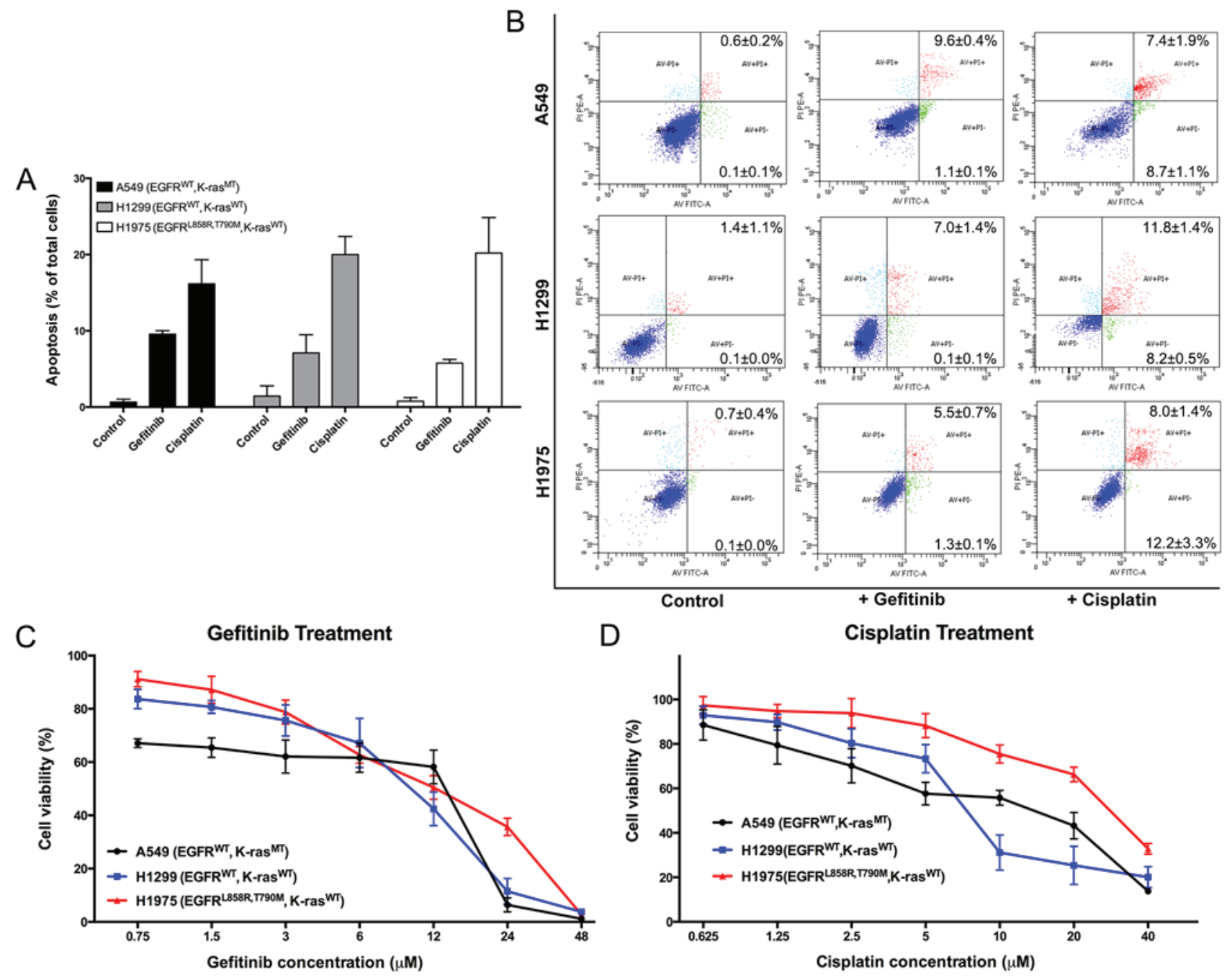

Figure 1. Sensitivity of the three non-small-cell lung cancer cells to gefitinib and cisplatin. (A) Apoptosis was assessed via Annexin V-FITC/PI dual staining using FACSCanto II. (B) Representative flow cytometry plots for all groups. (C) Cell viability after gefitinib treatment was determined via the MTT assay. (D) Cell viability after cisplatin treatment was determined via the MTT assay. WT, wild-type; MT, mutation type; K-ras, Kirsten rat sarcoma 2 viral oncogene homolog; PI, propidium iodide.

The CI value was $>1$ at most inhibition rate, indicating that the antagonist effect was stronger as the combination concentration of the two drugs increased (Fig. 2C-b). These three different NSCLC cells demonstrated different cisplatin and gefitinib combined effects (Table III).

Different sequential effects of gefitinib and cisplatin on different NSCLC cells. NSCLC cells were pretreated with
$15 \mu \mathrm{M}$ cisplatin for $72 \mathrm{~h}$ before gefitinib was administered or pretreated with $10 \mu \mathrm{M}$ gefitinib before cisplatin was administered to further assess the interaction between cisplatin and gefitinib on H1299, A549 and H1975 cells. No significant difference in gefitinib sensitivity on H1299 cells was observed with or without cisplatin pretreatment $(\mathrm{P}>0.05$; Fig. 3A-a). However, after $10 \mu \mathrm{M}$ gefitinib pretreatment, the sensitivity of H1299 cells to cisplatin was significantly higher compared with 
A a

H1299 (EGFR ${ }^{W T}, K^{\left.-R^{2}{ }^{W T}\right)}$

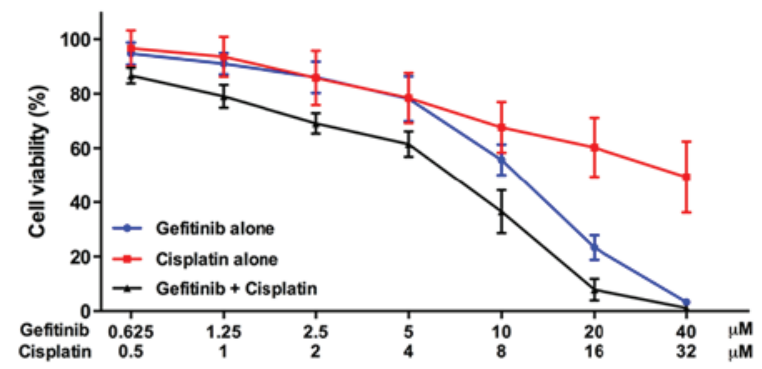

b

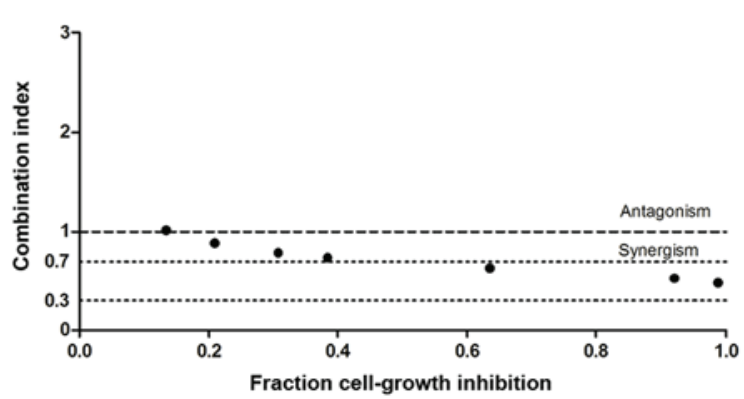

B a

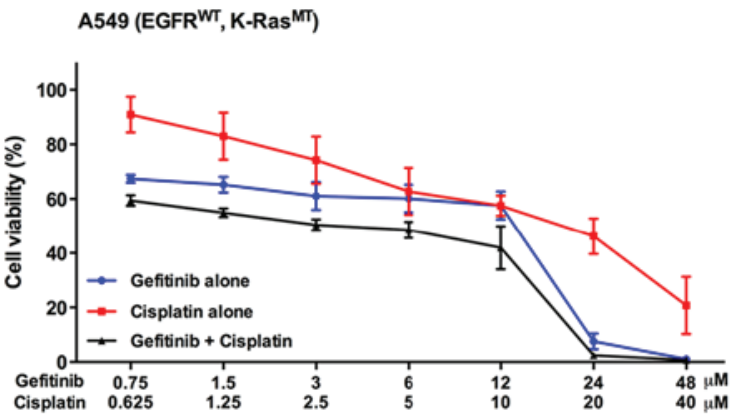

b

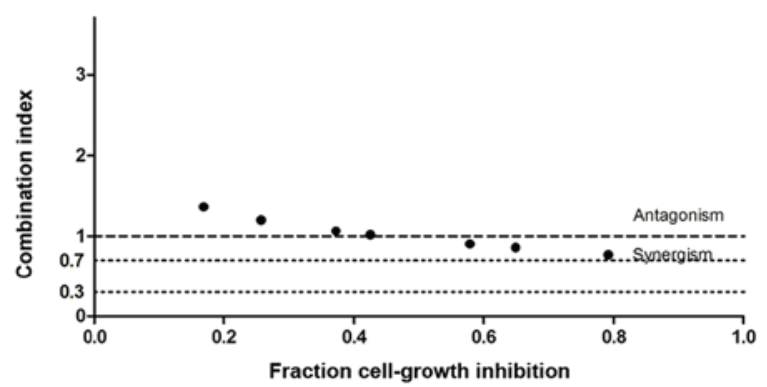

\section{C a}

H1975 (EGFR ${ }^{\text {L858R, T790M, K-Ras }}{ }^{\text {WT }}$ )

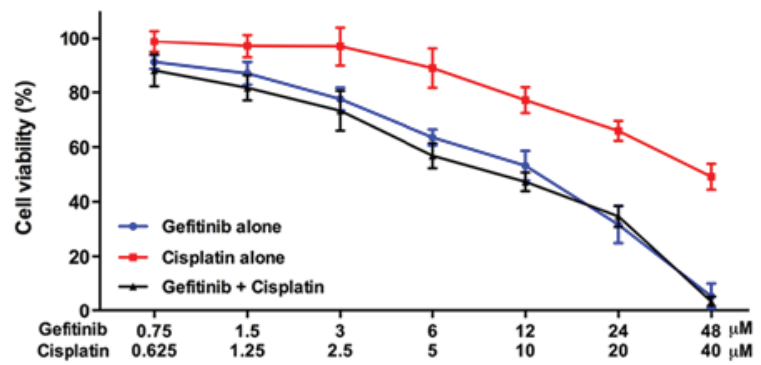

b

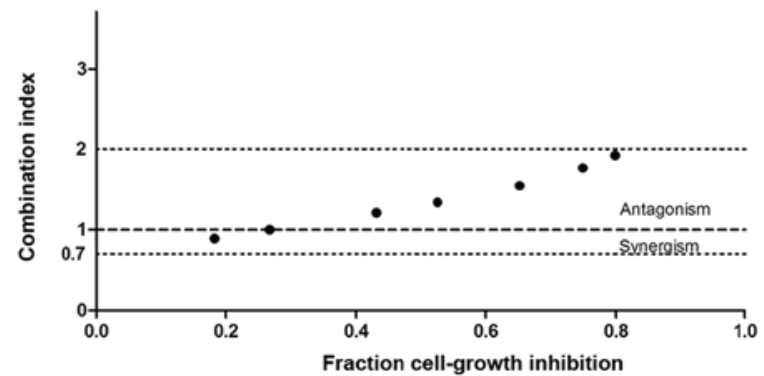

Figure 2. Synergistic, antagonistic and antiproliferative effects of gefitinib and cisplatin combination on non-small-cell lung cancer cells. Cell viability was determined using the MTT assay in (A-a) H1299, (B-a) A549 and (C-a) H1975 cells. CIs defining the proliferation inhibitory effects of the combination treatment of gefitinib and cisplatin in (A-b) H1299, (B-b) A549 and (C-b) H1975 cells. Combinations were antagonistic when CI >1.0, but synergistic when $\mathrm{CI}<1.0$. Points were the mean of three individual treatments. MT, mutation type; WT, wild-type; CI, combination index; K-ras, Kirsten rat sarcoma 2 viral oncogene homolog.

the cells without gefitinib pretreatment $(\mathrm{P}<0.05$; Fig. 3A-b). Thus, in $\mathrm{H} 1299$ cells, cisplatin pretreatment did not affect the antiproliferative effect of gefitinib, while gefitinib could enhance the inhibition of cisplatin. The sensitivity of gefitinib on cisplatin-pretreated A549 cells was significantly reduced (Fig. 3B-a), while cisplatin sensitivity was increased after gefitinib pretreatment (Fig. 3B-b). In H1975 cells, cisplatin reduced the sensitivity of gefitinib (Fig. 3C-a), and gefitinib had no significant effect on cisplatin (Fig. 3C-b). Moreover, the three types of NSCLC cells demonstrated different sequential effects of the two drugs (Table III).

Gefitinib selectively promotes cisplatin-induced apoptosis on H1299 and A549 cells. Cells were pretreated with $10 \mu \mathrm{M}$ gefitinib for $48 \mathrm{~h}$ and then treated with $15 \mu \mathrm{M}$ cisplatin for $48 \mathrm{~h}$ to investigate whether gefitinib could promote cisplatin-induced 
Table III. Combination and sequential effect of gefitinib and cisplatin on human non-small-cell lung cancer cell lines.

\begin{tabular}{llllll}
\hline Cell line & EGFR gene & K-Ras gene & \multicolumn{1}{c}{ G $+\mathrm{C}$} & $\mathrm{G} \rightarrow \mathrm{C}$ & $\mathrm{C} \rightarrow \mathrm{G}$ \\
\hline A549 & WT & G12S exon 2 & Synergistic/antagonistic & Sensitive & Inhibitive \\
H1299 & WT & WT & Synergistic & Sensitive & No effect \\
H1975 & L858R, T790M & WT & Antagonistic & No effect & Inhibitive
\end{tabular}

WT, wild type; $\mathrm{G}+\mathrm{C}$, combination of gefitinib and cisplatin; $\mathrm{G} \rightarrow \mathrm{C}$, gefitinib $\rightarrow$ cisplatin; $\mathrm{C} \rightarrow \mathrm{G}$, cisplatin $\rightarrow$ gefitinib; EGFR, epidermal growth factor receptor; K-ras, Kirsten rat sarcoma 2 viral oncogene homolog.

A a

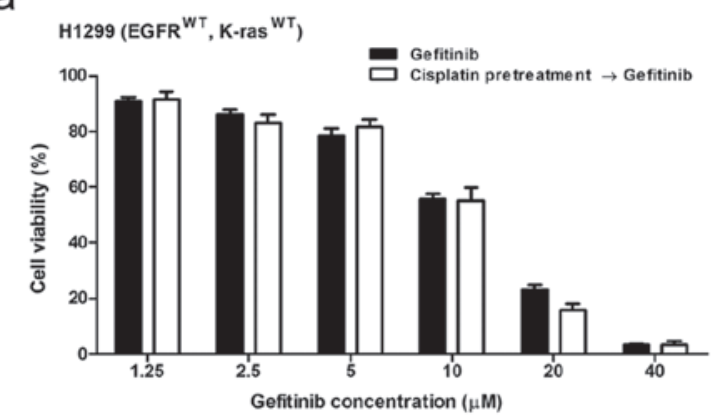

b

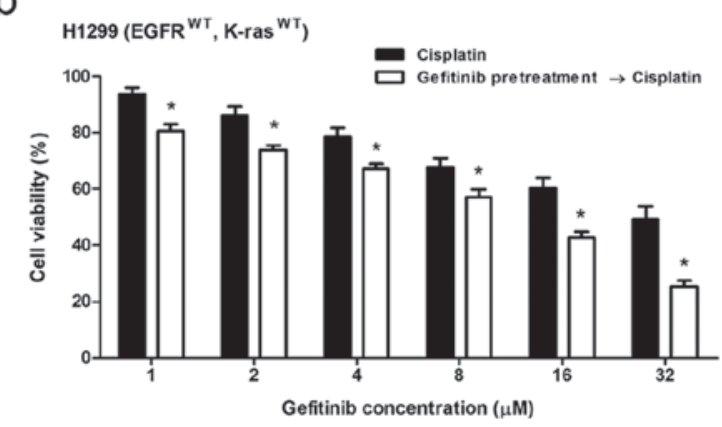

$\mathrm{B}$ a

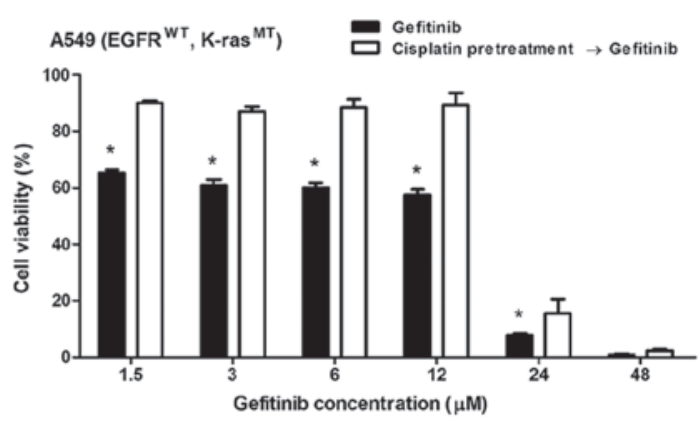

b

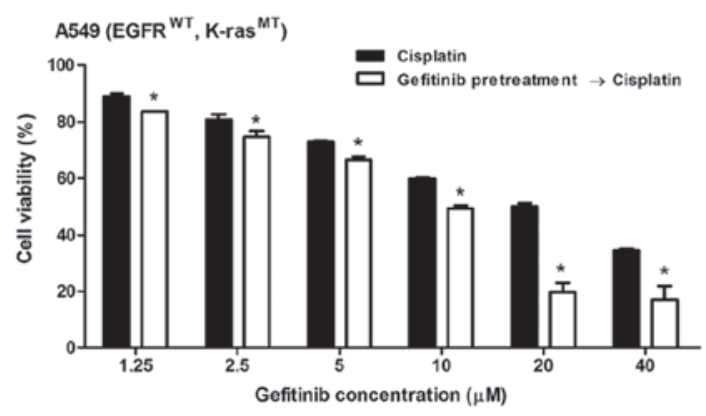

C a

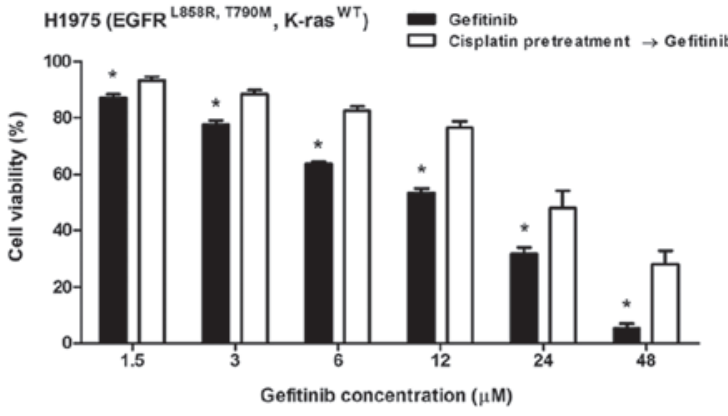

b

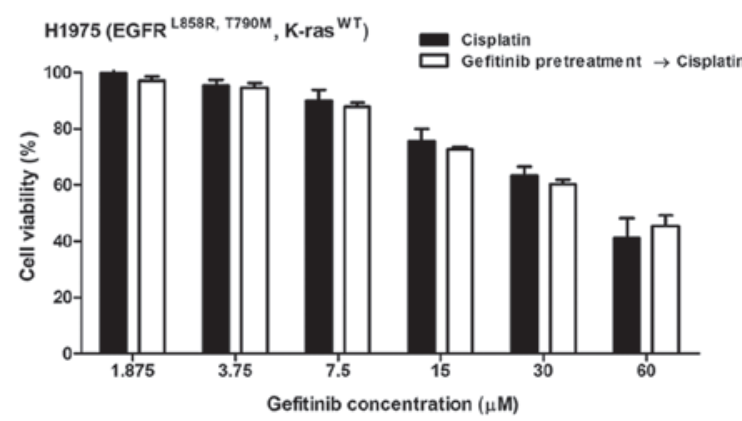

Figure 3. Sequential effects of gefitinib and cisplatin on non-small-cell lung cancer cells. Antiproliferative effect of gefitinib after cisplatin pretreatment for $72 \mathrm{~h}$ in (A-a) H1299, (B-a) A549 and (C-a) H1975 cells. Sensitivity of cisplatin after gefitinib pretreatment for 72 h in (A-b) H1299, (B-b) A549 and (C-b) H1975 cell. Cell viability was determined via the MTT assay. Data are presented as the mean \pm SEM of three experiments. $\mathrm{P}<0.05$, single drug groups vs. pretreatment groups. MT, mutation type; WT, wild-type; K-ras, Kirsten rat sarcoma 2 viral oncogene homolog. 
A
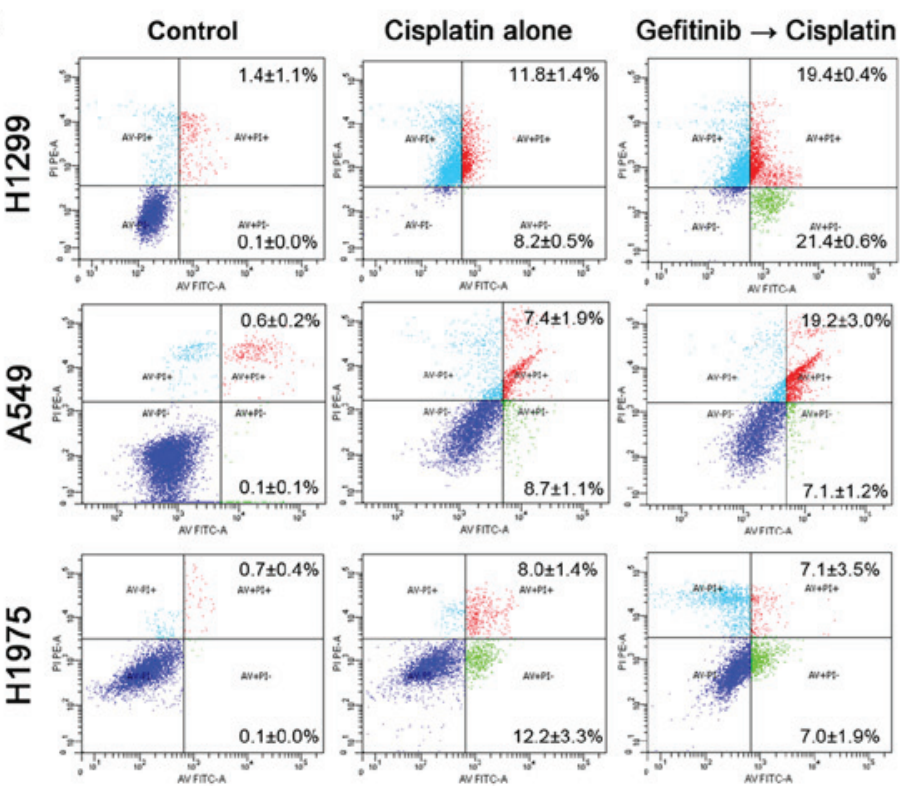

C

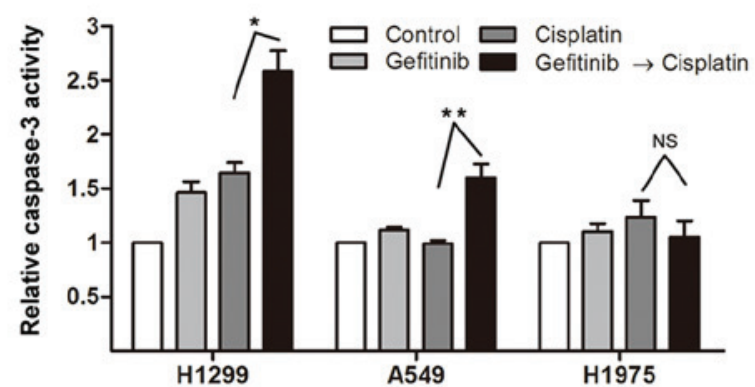

B
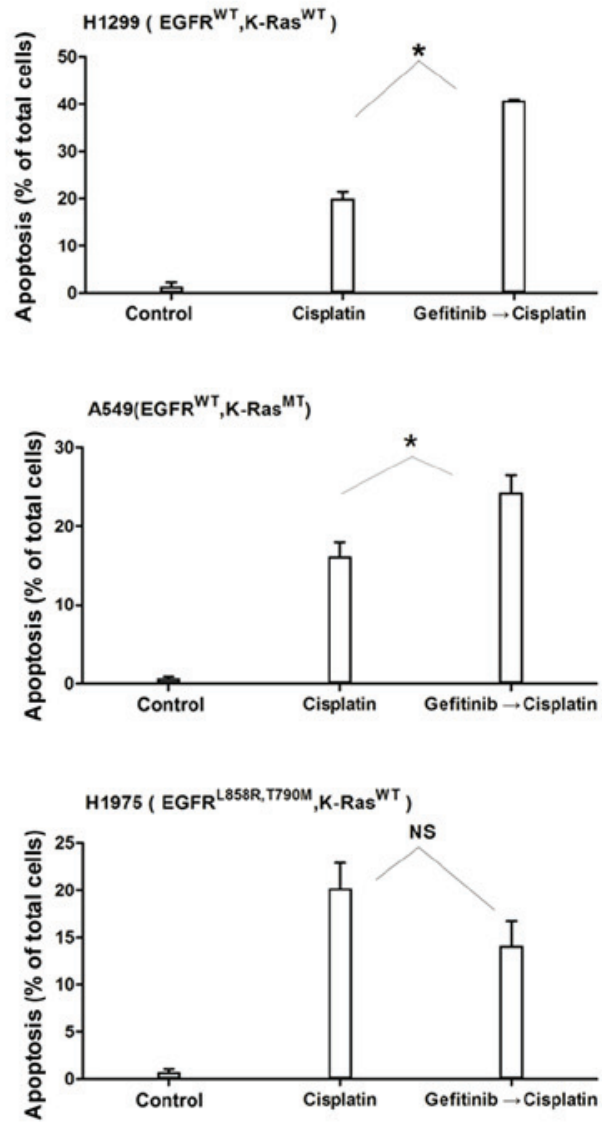

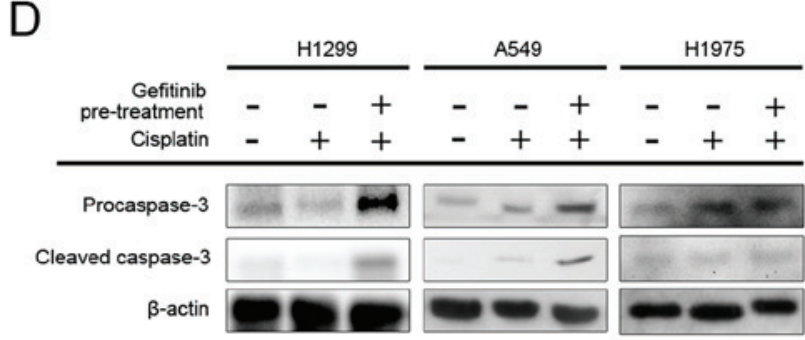

Figure 4. Cisplatin-induced apoptosis after gefitinib pretreatment on non-small-cell lung cancer cells. (A) Cisplatin-induced apoptosis promotion by gefitinib was analyzed using flow cytometry. (B) Statistical analysis of flow cytometry results from (A). (C) Relative caspase-3 activity after cisplatin and/or gefitinib treatment was determined using the caspase-3 Activity Assay kit. (D) Procaspase-3 and Cleaved caspase-3 expressions levels after treatments for 48 h. Data are presented as the mean \pm SEM. ${ }^{*} \mathrm{P}<0.05,{ }^{* *} \mathrm{P}<0.01$. NS, not significant; MT, mutation type; WT, wild-type; K-ras, Kirsten rat sarcoma 2 viral oncogene homolog.

apoptosis on H1299, A549 and H1975 cells. Apoptotic cells were detected via the AnnexinV-FITC/PI flow cytometry assay. For H1299 and A549 cells, the apoptotic rate of gefitinib pretreatment group was significantly higher compared with the cisplatin monotherapy group $(\mathrm{P}<0.05)$. However, no significant difference in $\mathrm{H} 1975$ cells was observed between the two groups ( $\mathrm{P}>0.05$; Fig. $4 \mathrm{~A}$ and $\mathrm{B})$. Therefore, the results suggested that gefitinib enhanced the apoptotic ability of cisplatin on H1299 and A549 cells.

The activation of caspase- 3 was detected via the caspase-3 Activity Assay kit according to the manufacturer's instructions, and the expression levels of caspase-3 precursor protein and cleaved caspase- 3 were detected by western blot analysis to determine whether caspase-3 activity after cisplatin administration could be enhanced by gefitinib pretreatment. The results demonstrated that caspase- 3 activity was more active and the expression levels of procaspase-3/cleaved caspase-3 proteins were increased after cisplatin treatment in the gefitinib pretreatment group compared with the cisplatin monotherapy group (Fig. 4C and D; P<0.05). However, no enhancement was observed in H1975 cells.

Gefitinib sensitizes the antitumor effect of cisplatin on H1299 and A549 tumorspheres. The 3D tumorspheres were cultured to simulate the cell growth environment in vitro, and the combination effect of cisplatin and gefitinib was monitored to assess the promotion of gefitinib on cisplatin-induced tumor inhibition.

Based on previous studies (34), RPMI-1640 medium was replaced with Matrigel at $10 \%$ volume ratio every 2 days 
A
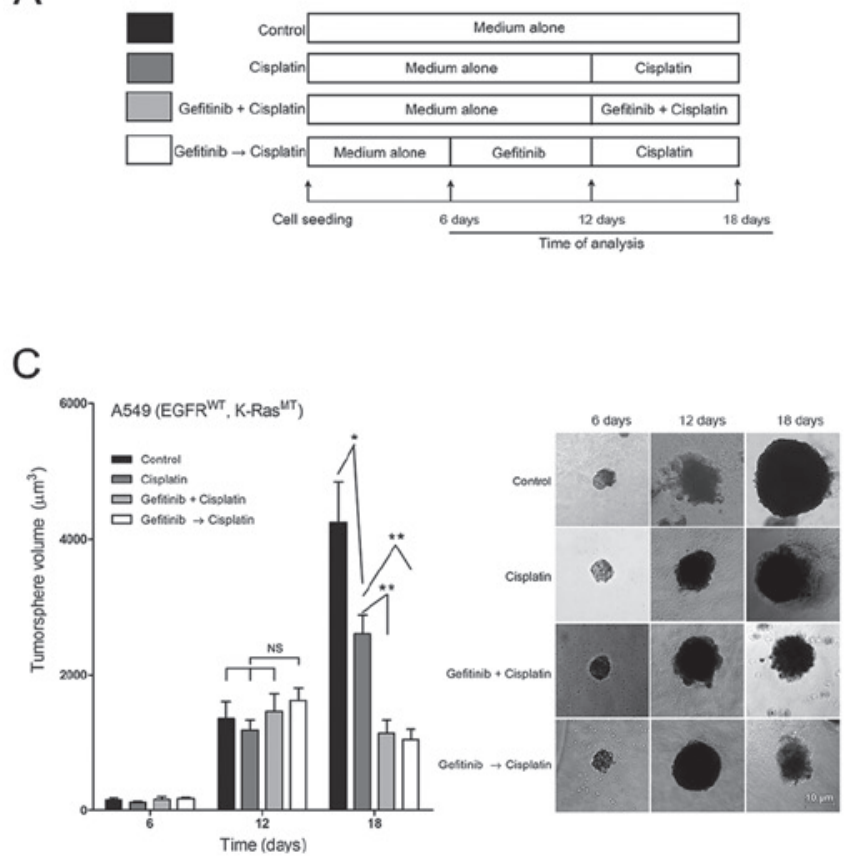

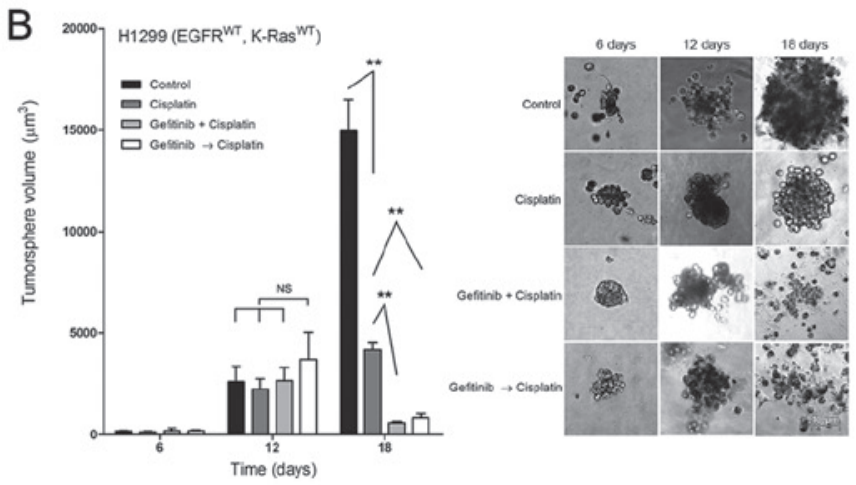

D

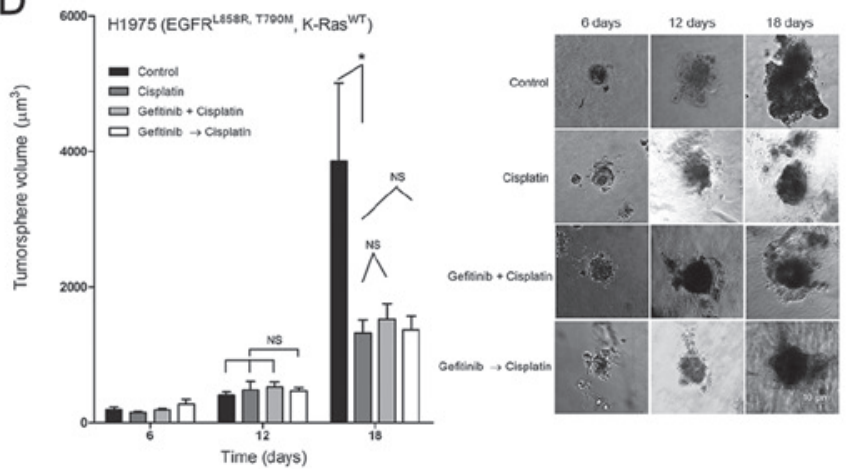

Figure 5. Antitumor effect of cisplatin and gefitinib on non-small-cell lung cancer tumorspheres under different treatment regimens. (A) Schematic diagram of four treatment regimens. (B) Volumes and images of H1299 tumorspheres. (C) Volumes and images of A549 tumorspheres. (D) Volumes and images of H1975 tumorspheres. Magnification, x20. Data are presented as the mean \pm SEM. ${ }^{*} \mathrm{P}<0.05,{ }^{* *} \mathrm{P}<0.01$. NS, not significant; G, gefitinib; C, cisplatin; MT, mutation type; WT, wild-type; K-ras, Kirsten rat sarcoma 2 viral oncogene homolog; d, days.

to ensure that cells could survive $>20$ days. NSCLC cells were treated with low-concentration $6 \mu \mathrm{M}$ gefitinib and high-concentration $20 \mu \mathrm{M}$ cisplatin, according to the treatment regimens (Fig. 5A). According to the growth trend of tumors in control group, the tumor growth was in a logarithmic rise phase on the 18th day (Fig. 5B-D). The tumor lengths were measured on 6, 12 and 18 days, and the tumorsphere volumes were also calculated. No significant difference in the tumorsphere volumes among the four groups were identified on the 6 and 12th day (Fig. 5B-D). However, on the 18th day, the tumorsphere volumes of H1299 in the four groups were as follows: $14,966.4 \pm 3,442.1,4,072.3 \pm 561.5,570.0 \pm 203.2$ and $871.5 \pm 472.6 \mu \mathrm{m}^{3}$, respectively. The tumor volumes of cisplatin monotherapy group were significantly reduced compared with the control group (Fig. 5B; $\mathrm{P}<0.01$ ). Furthermore, the volumes of $\mathrm{G}+\mathrm{C}$ and the $\mathrm{G} \rightarrow \mathrm{C}$ groups were significantly reduced compared with the cisplatin monotherapy group (Fig. 5B; both $\mathrm{P}<0.01)$. The volumes of A549 cells in the four groups were as follows: $4,252.7 \pm 2,383.4,2,610.2 \pm 997.4,1,138.6 \pm 592.3$ and $1,051.4 \pm 562.2 \mu \mathrm{m}^{3}$. The tumor volumes of $\mathrm{G}+\mathrm{C}$ with those of the $\mathrm{G} \rightarrow \mathrm{C}$ pretreatment groups were significantly reduced compared with the cisplatin monotherapy group (Fig. 5C; $\mathrm{P}<0.01$ ). The volumes of $\mathrm{H} 1975$ tumors were as follows: $3,856.7 \pm 3,661.2,1,321.6 \pm 915.8,1,530.5 \pm 977.3$ and $1,368.6 \pm 963.7 \mu \mathrm{m}^{3}$. No significant difference in tumor volumes between $\mathrm{G}+\mathrm{C}$ or $\mathrm{G} \rightarrow \mathrm{C}$ pretreatment groups and the cisplatin monotherapy groups were observed (Fig. 5D; $\mathrm{P}>0.05$ ). Collectively, the results indicated that gefitinib could selectively enhance the antitumor effect of cisplatin, which was present in H1299 and A549 cells but not H1975 cells.
Synergistic antiproliferative effect of gefitinib and cisplatin combination on $H 1299$ and A549 xenografts. A xenograft mouse model was used to study the effect on xenograft tumor growth in nude mice in vivo. H1299, A549 and H1975 cell suspensions were injected into the right flank of each mouse.

The mean \pm SEM of largest diameters of H1299 tumors in the control, gefitinib alone, cisplatin alone and gefitinib + cisplatin groups was: $16.31 \pm 3.58,15.02 \pm 1.49,12.9 \pm 1.73$ and $9.04 \pm 2.64 \mathrm{~mm}$ respectively. The mean \pm SEM in A549 tumors were: $8.14 \pm 1.42,8.62 \pm 0.65,6.99 \pm 1.55$ and $5.78 \pm 1.86 \mathrm{~mm}$. Furthermore, those in H1975 tumors were: 18.98 \pm 0.76 , $18.33 \pm 1.77,13.76 \pm 1.78$ and $13.77 \pm 1.62 \mathrm{~mm}$. The volumes and qualities of H1299 and A549 tumors were significantly reduced in the gefitinib + cisplatin group combination compared with gefitinib alone and cisplatin alone groups (Fig. 6A-a and b and B-a and b). However, in H1975 tumors, the combination of gefitinib + cisplatin did not significantly inhibit tumor growth compared with cisplatin alone group (Fig. 6A-c and B-c).

Subsequently, the results of tumor $\mathrm{H} \& \mathrm{E}$ staining indicated that in H1299 and A549 tumors, the tissue necrosis was more serious after a combination of gefitinib + cisplatin treatment compared with cisplatin monotherapy. However, no notable difference was observed in necrotic areas for H1975 tumors (Fig. 6C).

Gefitinib selectively inhibits DNA-PK activity on H1299 and A549 cells. The NSCLC cells were treated with $15 \mu \mathrm{M}$ cisplatin and $10 \mu \mathrm{M}$ gefitinib for $72 \mathrm{~h}$ to examine the mechanism of interaction between cisplatin and gefitinib. In addition, the activation and expression levels of the key proteins of the 
A a

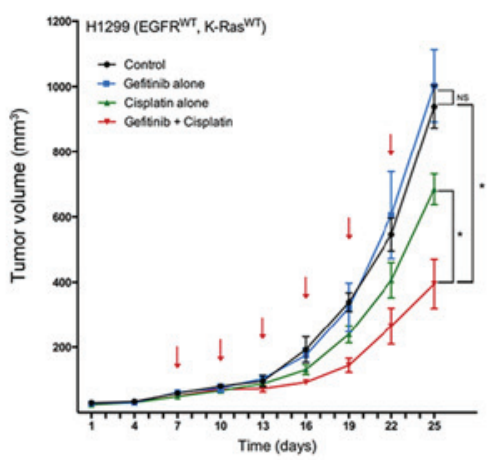

b

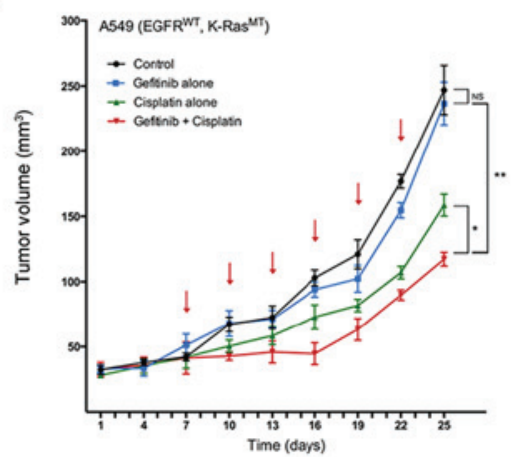

C

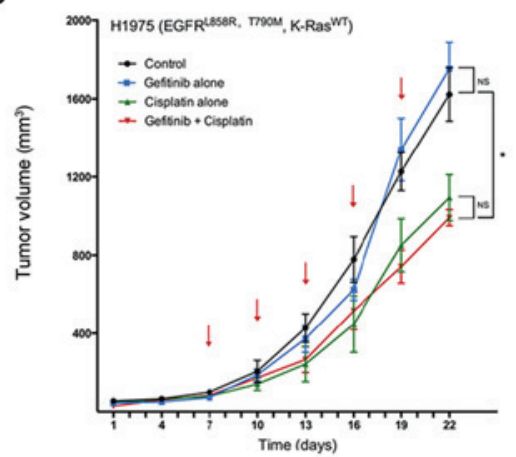

$\mathrm{B}$ a

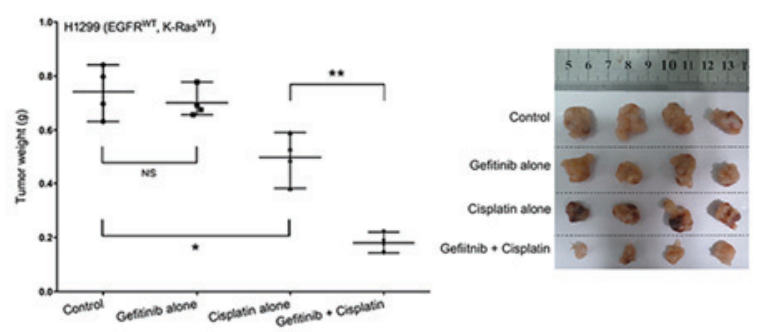

C

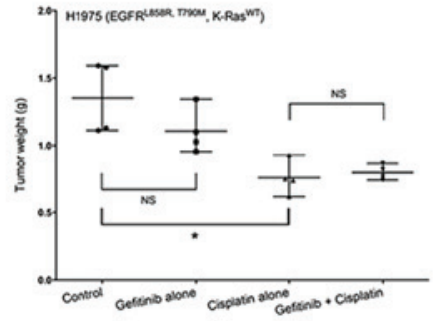

b

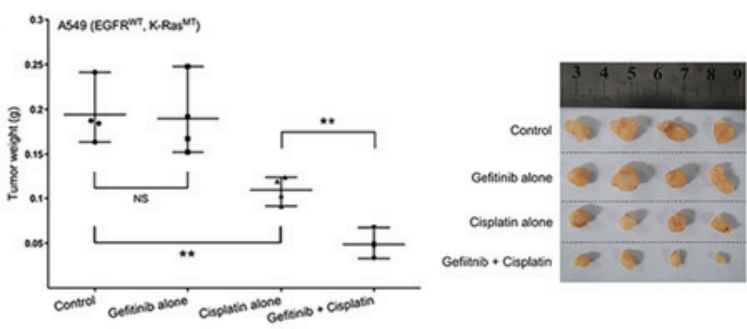

C
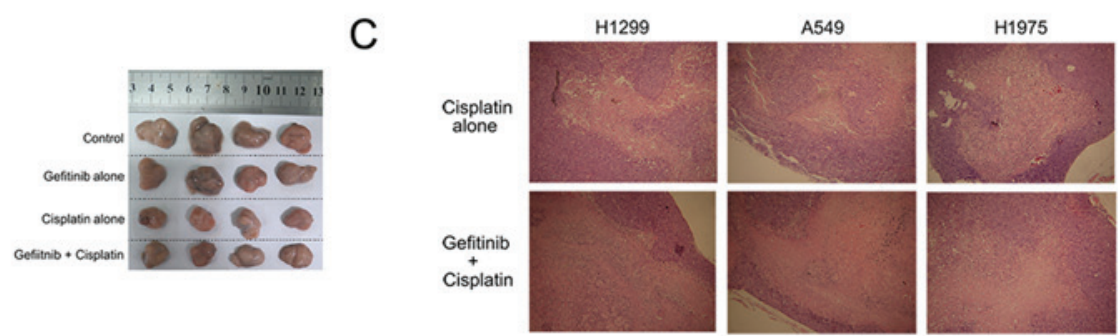

Figure 6. Effect of gefitinib and cisplatin combination on NSCLC xenografts. Tumor volume curves of each treatment group on three NSCLC xenografts, with in (A-a) H1299, (A-b) A549 and (A-c) H1975 cells. Tumor weights and images of three NSCLC xenografts with in (B-a) H1299, (B-b) A549 and (B-c) H1975 cells. (C) Paraffin-embedded tissue sections of the tumors were subjected to hematoxylin and eosin staining. Magnification, $x 40$. The red arrows indicate drug administration time. Data are presented as the mean $\pm \mathrm{SEM} .{ }^{*} \mathrm{P}<0.05,{ }^{* *} \mathrm{P}<0.01$. NS, not significant; MT, mutation type; WT, wild-type; K-ras, Kirsten rat sarcoma 2 viral oncogene homolog; NSCLC, non-small-cell lung cancer.

EGFR pathway and platinum-sensitive associated proteins, such as Akt,Erk1/2,PTEN, BRCA1 and ERCC1, were detected via western blot analysis. The results identified that both gefitinib alone and in combination with cisplatin could decrease the expression levels of p-Akt and p-Erk1/2 in H1299, A549 and H1975 cells in comparison with the control group, while cisplatin alone had no effect on the expression levels of p-Akt and $\mathrm{p}-\mathrm{Erk} 1 / 2$. Cisplatin monotherapy, gefitinib monotherapy and combination therapy of the two drugs had no effect on the expression of PTEN and ERCC1 proteins in the three cells. Moreover, cisplatin monotherapy and cisplatin + gefitinib could increase the expression of p-BRCA1 in the three cells, but gefitinib monotherapy did not have the same effect. The changes in the activation and expression levels of the above proteins were all consistent in H1299, A549 and H1975 cells (Fig. 7A).

Subsequently, the expression and activation status of EGFR and DNA-PK in the three cell lines were examined. After $15 \mu \mathrm{M}$ cisplatin treatment alone for $72 \mathrm{~h}$, the expression levels and phosphorylation of EGFR and DNA-PK did not change in these three NSCLC cells. Although the EGFR and DNA-PK expression levels of the three cells did not change significantly after $10 \mu \mathrm{M}$ gefitinib monotherapy for $72 \mathrm{~h}$, the expression levels of p-EGFR and p-DNA-PK decreased in H1299 and A549 cells. p-EGFR in H1975 cells was also inhibited, but no notable change was observed in DNA-PK phosphorylation. After the combination of $15 \mu \mathrm{M}$ cisplatin and $10 \mu \mathrm{M}$ gefitinib, the expression levels of EGFR and DNA-PK in the three NSCLC cells remain unchanged, and the phosphorylation levels of EGFR and DNA-PK of the H1299 and A549 cells were reduced. Furthermore, p-EGFR in H1975 cells was also inhibited, but p-DNA-PK was unchanged (Fig. 7B). Therefore, it was speculated that gefitinib selectively inhibited the pathway of DNA-PK phosphorylation in H1299 and A549 cells, and this inhibition was not associated with EGFR phosphorylation.

Gefitinib selectively inhibits EGFR binding to DNA-PK in $H 1299$ and A549 cells. To further examine whether gefitinib could inhibit DNA-PK activation, NSCLC cells were treated with $20 \mathrm{nM}$ NU7441 (DNA-PK specific inhibitor), $10 \mu \mathrm{M}$ gefitinib and a combination of different cisplatin concentrations at $37^{\circ} \mathrm{C}$ in an incubator for $72 \mathrm{~h}$. In $\mathrm{H} 1299$ and A549 cells, the effect of $20 \mathrm{nM}$ NU7441 combined with cisplatin on cell viability had a synergistic effect similar to that of the combination of gefitinib + cisplatin. Moreover, the synergistic 


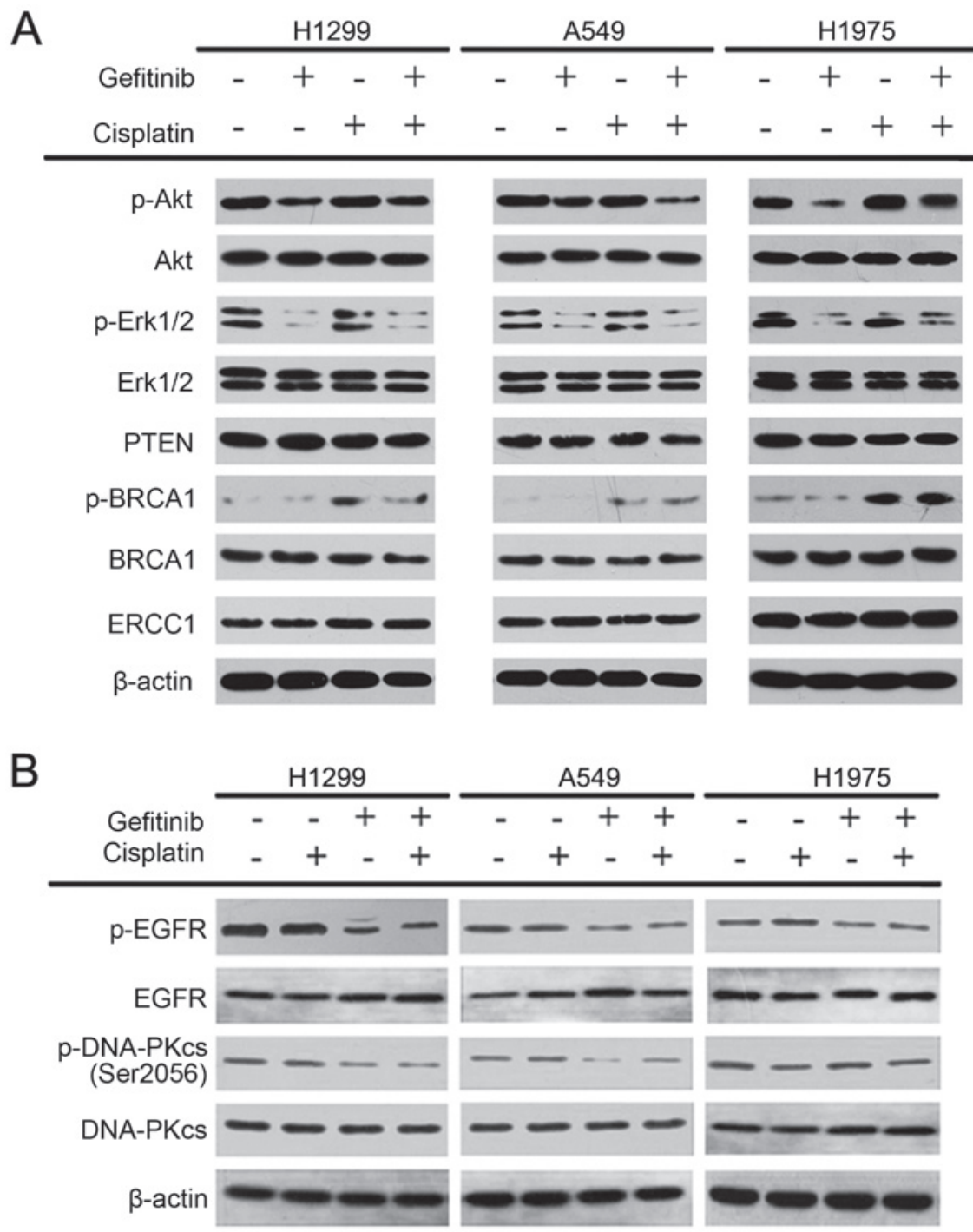

Figure 7. Activation and expression levels of Akt, Erk1/2, BRCA1, PTEN, ERCC1, EGFR and DNA-PKcs on the three non-small-cell lung cancer cells after different treatments. (A) Effects of Akt, Erk1/2, BRCA1, PTEN, and ERCC1 on cisplatin combined with gefitinib. (B) Expression levels and activation of EGFR and DNA-PKcs in the three NSCLC cells after the combination of gefitinib and cisplatin. p-, phosphorylated; BRCA1, BRCA1 DNA repair associated; ERCC1, ERCC excision repair 1, endonuclease non-catalytic subunit; DNA-PK, DNA-dependent protein kinase; EGFR, epidermal growth factor receptor.

effect of the combination of NU7441, gefitinib and cisplatin was not stronger than that of the combined NU7441 and cisplatin. However, no synergy in the combination of gefitinib and cisplatin group was observed in the H1975 cells (Fig. 8A). In addition, H1299 and A549 cells pretreated with $20 \mathrm{nM}$ NU7441 were highly sensitive to cisplatin, and this effect was similar to that of the gefitinib pretreatment $(10 \mu \mathrm{M}$ gefitinib at $37^{\circ} \mathrm{C}$ for $72 \mathrm{~h}$ ). However, the effect could not be enhanced by treatment with NU7441 and gefitinib simultaneously (Fig. 8B). Therefore, the data indicated that the synergistic effect of gefitinib combined with cisplatin was achieved via the gefitinib inhibition of the DNA-PK activity (Fig. 8B).

The interaction of EGFR and DNA-PK was further detected via IP after treatment with $15 \mu \mathrm{M}$ cisplatin and $10 \mu \mathrm{M}$ gefitinib for $72 \mathrm{~h}$. The results suggested that the IP of EGFR and DNA-PK was positive in all three NSCLC cells without any drug treatment (Fig. 8C). After treatment with cisplatin alone, the IP results of EGFR and DNA-PK of these three cells were not notably different from those of the untreated cells. However, the IP of EGFR and DNA-PK in H1299 and A549 cells was markedly attenuated after gefitinib treatment, but no notable change in H1975 cells was observed (Fig. 8C). Thus, an interaction may occur between EGFR and DNA-PK in the NSCLC cells, and gefitinib could selectively inhibit the interaction between EGFR and DNA-PK in H1299 and A549 cells.

Gefitinib selectively blocks EGFR translocation into the nucleus of H1299 and A549 cells. It was found that DNA-PK was mainly distributed in the nucleus, and cisplatin + gefitinib could not interfere with the DNA-PK distribution. Furthermore, EGFR was evenly distributed in the cytoplasm and nucleus of these cell lines, and EGFR in the nucleus of H1299 and A549 cells was relatively decreased after treatment containing gefitinib (Fig. 9A and B). However, gefitinib did not interfere with EGFR in the nucleus of H1975 cells (Fig. 9C). Western blotting results demonstrated that gefitinib-containing treatment reduced the nuclear EGFR expression of H1299 and A549 cells, and the corresponding cytosolic EGFR expression levels were increased. However, gefitinib had no effect on EGFR in H1975 cells (Fig. 9D). The results indicated that DNA-PK was 

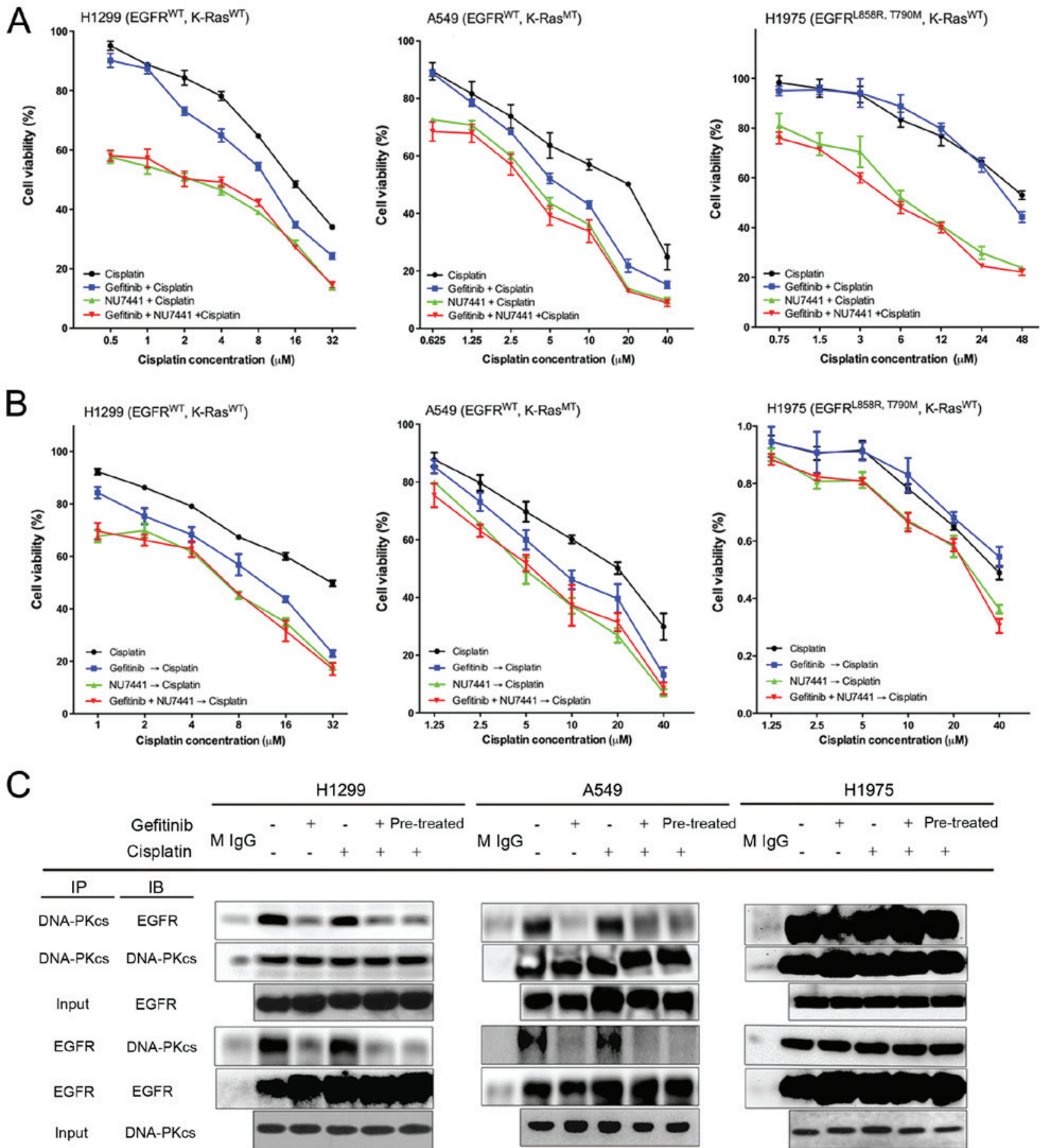

$\frac{\mathrm{H} 1975}{\mathrm{M} \lg \mathrm{-}_{-}+{ }_{-}+\text {Pre-treated }}$

\begin{tabular}{lll}
\hline \multicolumn{1}{c}{ IP } & \multicolumn{1}{c|}{ IB } \\
DNA-PKcs & EGFR \\
DNA-PKcs & DNA-PKcs \\
Input & EGFR \\
EGFR & DNA-PKcs \\
EGFR & EGFR
\end{tabular}
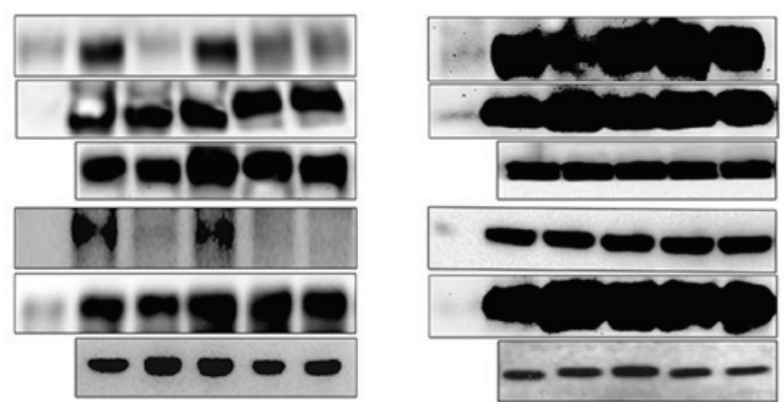

Figure 8. Inhibition of EGFR and DNA-PK by gefitinib in three non-small-cell lung cancer cells. (A) Combination effects of UN7441, gefitinib and cisplatin on the cell viability of the three NSCLC cells. (B) Sequential effects of UN7441, gefitinib and cisplatin on the cell activity of the three cell lines. (C) Interaction of EGFR and DNA-PKcs was detected via immunoprecipitation. DNA-PK, DNA-dependent protein kinase; EGFR, epidermal growth factor receptor; MT, mutation type; WT, wild-type; K-ras, Kirsten rat sarcoma 2 viral oncogene homolog.

mainly distributed in the nucleus of NSCLC cells, while EGFR was almost evenly distributed in the cytoplasm and nucleus. Thus, gefitinib could selectively prevent the nuclear enrichment of EGFR in H1299 and A549 cells, but could not prevent translocation of EGFR into the nucleus of the H1975 cells.

\section{Discussion}

The sensitivity of NSCLC cells to gefitinib depends on whether EGFR genes harbor sensitive mutations, such as EGFR 19 exon deletion and exon 21 L858R mutation. Furthermore, patients with these mutations are likely to benefit from EGFR-TKIs drugs $(5,6)$. However, Westover et al (35) reported that wild-type EGFR, K-ras mutation and secondary EGFR mutation (exon 20 T790M) were associated with resistance to EGFR-TKIs. Zhang et al (36) also revealed that the genotypes of EGFR and K-ras in the NSCLC cell line A549 were EGFR wild type and K-ras mutation (exon 2 G12S), which could explain the resistance of A549 to EGFR-TKI $(37,38)$. The genotypes of EGFR-TKI-resistant 

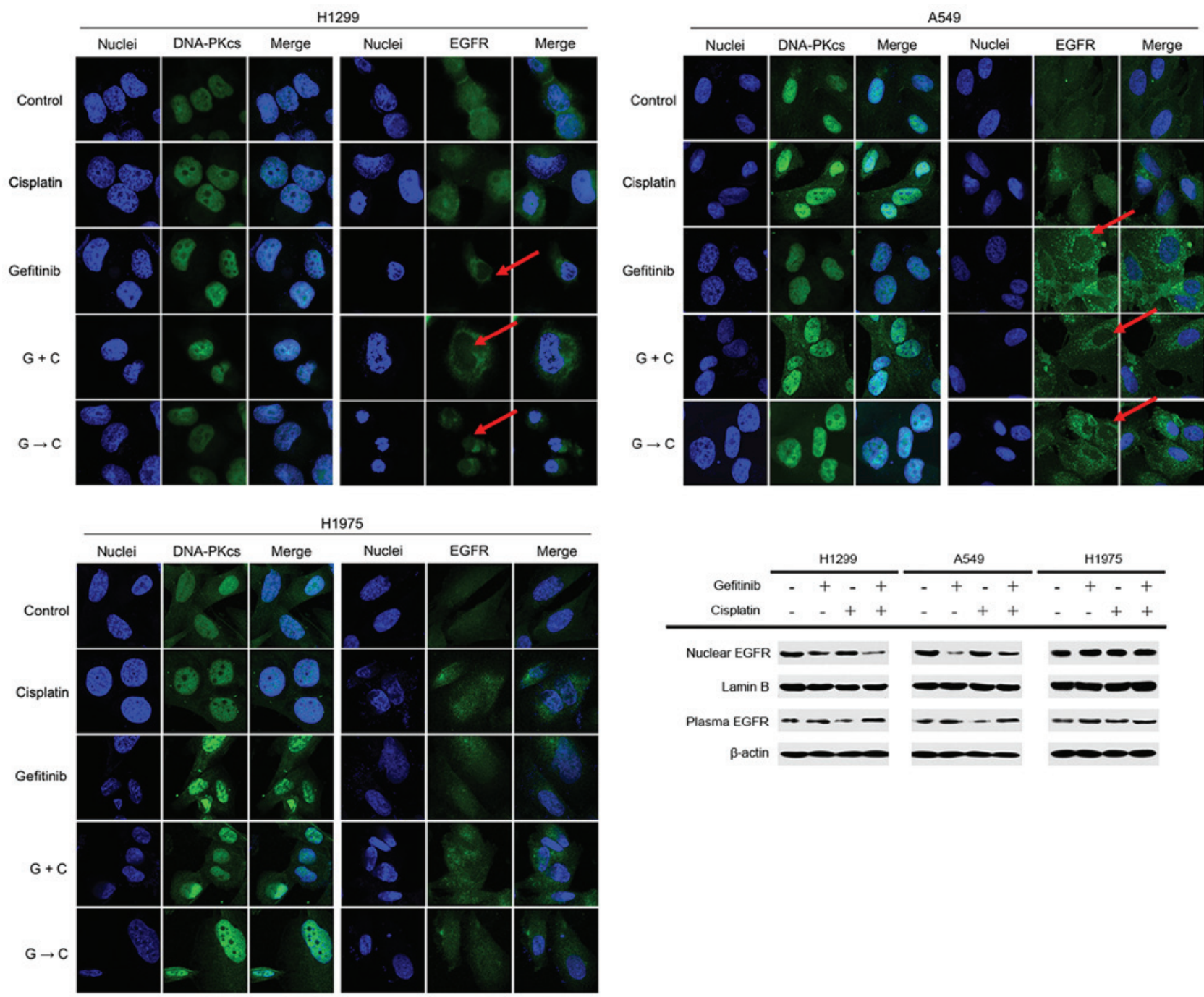

Figure 9. Distribution of EGFR and DNA-PKcs interfered by cisplatin and gefitinib. Cytoplasm and nucleus of cells were shown in each panel. Distributions of EGFR and DNA-PKcs were detected via immunofluorescence. The expression levels of cytoplasm and nuclear EGFR were detected via western blot analysis. The red arrows indicate nucleus without EGFR. DNA-PK, DNA-dependent protein kinase; EGFR, epidermal growth factor receptor; G, gefitinib; C, cisplatin.

H1299 cell line have been shown to be wild-type EGFR and wild-type K-ras (39). In addition, the H1975 cell line with secondary EGFR mutation (exon $20 \mathrm{~T} 790 \mathrm{M})$ and exon 21 L858R mutation (36) developed a secondary resistance to EGFR-TKIs (40). All three cell lines have been analyzed and verified with the gefitinib-resistant NSCLC models, and it has been reported that the EGFR and K-ras genotypes of A549, H1299 and H1975 cell lines are different. For example, A549 and H1299 cells with wild-type EGFR are primarily resistant to gefitinib $(39,41,42)$, while H1975 harbors EGFR L858R-sensitive mutation in exon 21 (43) and secondary resistant mutation T790M. The mutation sites of A549, H1299 and H1975 cells in the present study were consistent with the literature (44). It has been reported that the cells resistance to EGFR-TKIs if $\mathrm{IC}_{50}>2 \mu \mathrm{M}(38,45)$, but patients with wild-type EGFR may still benefit from EGFR-TKIs in the clinical practice (46). The present results suggested that these three types of NSCLC cell models were all EGFR-TKI resistant, and their $\mathrm{IC}_{50}$ values were $\sim 10 \mu \mathrm{M}$.

The combined effects of cisplatin and gefitinib were shown to be inconclusive in previous studies $(40,47)$. For instance,
Tsai et al (47) reported that these two drugs had no synergetic effects on NSCLC cells, but Laurila and Koivunen (48) suggested otherwise. In the present study, it was found that cisplatin + gefitinib combination produced different effects among the three NSCLC cell lines. It was demonstrated that gefitinib monotherapy significantly inhibited the viability of three NSCLC cells in vitro. Moreover, cisplatin improved the antiproliferative effect of gefitinib in H1299 and A549 cells in vivo and in vitro, but such effect was not observed in H1975 cells.

Zhang et al (49) reported that some patients with advanced NSCLC with wild-type EGFR could benefit from the combination therapy of EGFR-TKI and platinum-based drugs. The present results suggested that the combination effects of gefitinib and cisplatin in H1299 and A549 varied, despite both cells containing wild-type EGFR. For example, H1299 cells had a consistent synergistic effect in vitro, while A549 cells had a complex mixture effect with regards to synergy. Thus, it was speculated that wild-type EGFR could not be used as a single biomarker to predict the combined effect of cisplatin and gefitinib. Hierarchical analyses of 
most previous clinical trials are based on EGFR genotype, which may explain the contradictory conclusions from the literature $(9,14,15,49)$. Moreover, the biological difference of tumors may cause this inconsistency. The most obvious differences between the H1299 and A549 cells is that H1299 contains wild-type K-ras, but A549 has the most common mutant of exon 2 G12S. Previous studies have revealed that the K-ras mutation was a mechanism for primary resistance to EGFR-TKI (50), and this could be an indicator for excluding the combination of erlotinib and platinum-based chemotherapy (51). In the present study, gefitinib and cisplatin had extensive synergistic effects in A549 cells with mutant K-ras (exon 2 G12S), but their effects were completely different in H1975 and H1299 cells with wild-type K-ras. Thus, both the present study and previous reports $(47,51,52)$ suggested that the EGFR and K-ras gene status are not reliable indictors to assess the sensitivity of combination treatments.

The Iressa Mutation-Positive Multicenter Treatment Beyond ProgRESsion Study (IMPRESS) trial reported that gefitinib-platinum combination therapy was ineffective in patients with secondary resistance and who were carriers of the EGFR T790M mutation, but the treatment was effective in patients with secondary resistance and who were non-carriers of the T790M mutation (53). Moreover, biomarker analyses suggested that this effect may be driven by the T790M-positive status (53). In the present study, an antagonistic effect was observed in the H1975 cells with the EGFR T790M mutation and this observation was consistent with IMPRESS results, which that may be explained via the synergistic mechanisms between gefitinib and cisplatin that were investigated in the current study. However, no biomarker is available to predict the benefit of the combination therapy.

In the current study, it was indicated that the synergistic effect of cisplatin and gefitinib depended on the increased sensitivity of cisplatin induced by gefitinib. The two drugs demonstrated antagonistic effect in A549 cells when combined at low concentrations, but the effect became synergistic at high concentrations. Therefore, sensitization of gefitinib on cisplatin was dominant at high concentrations. The mechanisms of sensitization could provide novel ideas for investigating new biomarkers for combination therapy.

The present results demonstrated that gefitinib enhanced cisplatin-induced apoptosis in H1299 and A549 cells and activation of caspase-3, but this phenomenon was not observed in H1975 cells. Previous studies have shown that gefitinib could enhance the antitumor ability of cisplatin in clinical practice (54), and some patients with NSCLC with failed platinum-based chemotherapy could resume chemotherapy after treatment of gefitinib for a period of time (55). In the present study, cisplatin inhibited the sensitivity of gefitinib, and this result was different from previous findings $(40,56)$. It was speculated that this difference may be associated with the biological background of NSCLC models. Therefore, the inhibition mechanism of cisplatin on gefitinib requires further examination in future studies.

EGFR has two main downstream signal pathways: The Ras/Raf/Mitogen-activated protein kinase kinase/ERK/ Mitogen-activated protein kinase pathway (57) and the PI3K/Akt/mTOR pathway (58). The core agents of these two pathways are ERK1/2 and Akt proteins, respectively, and EGFR-TKI can inhibit the activation of EGFR downstream pathways via EGFR activation inhibition (45). PTEN is a tumor suppressor protein that blocks the activation of Akt and its related proteins (59), and the deletion or inhibition of PTEN is associated with EGFR-TKI resistance (60-62). Previous studies have shown that the mechanism of the synergistic effects between cisplatin and gefitinib was associated with cisplatin-induced activation of EGFR pathway (40). However, in the current study, this pathway was not observed in all three NSCLC cells.

The present results indicated that DNA-PK phosphorylation could be inhibited by gefitinib in H1299 and A549 cells but not in H1975 cells. Previous studies also revealed that gefitinib inhibited DNA-PK activity in breast cancer cells and decreased DNA-PK phosphorylation $(63,64)$. However, gefitinib had no effect on BRCA1 activation and ERCC1 expression. Moreover, BRCA1 was activated by cisplatin, which may be the stress response of cisplatin. Thus, it was speculated that the synergistic effect between gefitinib and cisplatin in NSCLC cells may be achieved via the inhibition of the DNA-PK pathway.

An interaction between EGFR and DNA-PK was identified in the NSCLC cell nucleus, and the interaction could be selectively inhibited by gefitinib. In addition, the present results suggested that the amount of EGFR in the nucleus could be reduced by gefitinib. Therefore, gefitinib may prevent EGFR from entering the nucleus, thus activating DNA-PK and sensitizing cisplatin. The synergistic effect between gefitinib and cisplatin may due to the enhanced cytotoxicity of cisplatin by gefitinib. Similar mechanisms have also been reported in previous studies, which showed that EGFR could move into the nucleus and bind to DNA-PK to assist in DNA double-strand repair, enhancing tumor cell repair $(28,29,63,65)$. Cetuximab, an EGFR antibody, has also been showed to prevent EGFR from entering the nucleus and inhibiting DNA-PK activity, which increases the sensitivity of chemotherapy $(65,66)$.

Nuclear EGFR can regulate the translation of cell signaling proteins (67). Furthermore, not all types of EGFR can enter the nucleus. It has been revealed that cisplatin and radiation facilitate the wild-type EGFR and EGFR vIII entering the nucleus, but not EGFR with the L858R multination (32). EGFR vIII is an EGFR mutation and it lacks the extracellular ligand-binding region factor (32). The inability of ligand binding inhibits the intracellular activation of EGFR and causes the resistance to EGFR-targeted drugs (68). As H1299 and A549 cells contain wild-type EGFR, and H1975 harbors L858R mutation, it was speculated that wild-type EGFR may be an essential agent for the sensitization of cisplatin by gefitinib.

In conclusion, the present results suggested that gefitinib can selectively inhibit DNA-PK activity and sensitize the cytotoxicity of cisplatin in NSCLC cells by inhibiting nuclear EGFR to active DNA-PK, which is the synergistic mechanism between platinum-based chemotherapy and EGFR-TKI. In addition, wild-type EGFR may be a potential biomarkers for the selection of combination therapy of cisplatin-based chemotherapy and gefitinib; however, further research is required to identify other biomarkers. 


\section{Acknowledgements}

The authors would like to thank Dr Qinghua Lv, Dr Qi Dong and Dr Jiaping Peng (Cancer Institute, Zhejiang University) for technical support in the laboratory. The authors would also like to thank Dr Xiangyin Wei (Food and Drug Administration) for language modification of the manuscript.

\section{Funding}

This work was supported by research grants from the Zhejiang Provincial Natural Science Foundation of China (grant nos. LQ17H160012, LQ19H160041 and LY17H160013), the China Natural Science Foundation projects (grant nos. 81602516, 81402365, 81502598 and 81602716), the Foundation of Education Department of Zhejiang Province (grant no. Y201636729), the Key Program of the Natural Science Foundation of Zhejiang Province (grant no. LZ16H160002) and the Zhejiang Provincial Program for the Cultivation of High-level Innovative Health Talents to YDC, Training Program of the Major Research Plan of the National Science Foundation of China (grant no. 91229104).

\section{Availability of data and materials}

The datasets used or analyzed during the current study are available from the corresponding author on reasonable request.

\section{Authors' contributions}

JJH and SZZ conceived the concept and designed the study. CP, HJD, YNW, CPZ, CHY, YD, DML, CG, DQW, YYW, XHF, JX, ML, YDC, TP and WT performed the experiments. CP and HJD wrote the paper. YDC, TP and WHX reviewed and edited the manuscript. All authors read and approved the manuscript.

\section{Ethics approval and consent to participate}

All of the animal experiments described in this study were approved by the Institutional Animal Care and USE Committee (IACUC) at Zhejiang University. All animals were maintained in accordance with the IACUC guideline.

\section{Patient consent for publication}

Not applicable.

\section{Competing interests}

The authors declare that they have no competing interests.

\section{References}

1. Ferlay J, Colombet M, Soerjomataram I, Mathers C, Parkin DM, Piñeros M, Znaor A and Bray F: Estimating the global cancer incidence and mortality in 2018: GLOBOCAN sources and methods. Int J Cancer 144: 1941-1953, 2019.

2. Bray F, Ferlay J, Soerjomataram I, Siegel RL, Torre LA and Jemal A: Global cancer statistics 2018: GLOBOCAN estimates of incidence and mortality worldwide for 36 cancers in 185 countries. CA Cancer J Clin 68: 394-424, 2018.
3. Burdett S, Stewart L and Pignon JP: Chemotherapy in non-small cell lung cancer: An update of an individual patient data-based meta-analysis. J Thorac Cardiovasc Surg 129: 1205-1206, 2005.

4. NSCLC Meta-Analyses Collaborative Group: Chemotherapy in addition to supportive care improves survival in advanced non-small-cell lung cancer: A systematic review and meta-analysis of individual patient data from 16 randomized controlled trials. J Clin Oncol 26: 4617-4625, 2008.

5. Baselga J and Averbuch SD: ZD1839 ('Iressa') as an anticancer agent. Drugs 60 (Suppl 1): S33-S42, 2000.

6. Singh M and Jadhav HR: Targeting non-small cell lung cancer with small-molecule EGFR tyrosine kinase inhibitors. Drug Discov Today 23: 745-753, 2018.

7. Wu SG and Shih JY: Management of acquired resistance to EGFR TKI-targeted therapy in advanced non-small cell lung cancer. Mol Cancer 17: 38, 2018

8. Jänne PA, Yang JC, Kim DW, Planchard D, Ohe Y, Ramalingam SS, Ahn MJ, Kim SW, Su WC, Horn L, et al: AZD9291 in EGFR inhibitor-resistant non-small-cell lung cancer. N Engl J Med 372: 1689-1699, 2015.

9. Yang JC, Hirsh V, Schuler M, Yamamoto N, O'Byrne KJ, Mok TS, Zazulina V, Shahidi M, Lungershausen J, Massey D, et al: Symptom control and quality of life in LUX-Lung 3: A phase III study of afatinib or cisplatin/pemetrexed in patients with advanced lung adenocarcinoma with EGFR mutations. J Clin Oncol 31: 3342-3350, 2013.

10. Takeda H, Takigawa N, Ohashi K, Minami D, Kataoka I, Ichihara E, Ochi N, Tanimoto M and Kiura K: Vandetanib is effective in EGFR-mutant lung cancer cells with PTEN deficiency. Exp Cell Res 319: 417-423, 2013.

11. Costa DB, Shaw AT, Ou SH, Solomon BJ, Riely GJ, Ahn MJ,Zhou C, Shreeve SM, Selaru P, Polli A, et al: Clinical experience with crizotinib in patients with advanced ALK-rearranged non-small-cell lung cancer and brain metastases. J Clin Oncol 33: 1881-1888, 2015.

12. Zhang Z, Luo F, Zhang Y, Ma Y, Hong S, Yang Y, Fang W, Huang Y, Zhang L and Zhao H: The ACTIVE study protocol: Apatinib or placebo plus gefitinib as first-line treatment for patients with EGFR-mutant advanced non-small cell lung cancer (CTONG1706). Cancer Commun (Lond) 39: 69, 2019.

13. Kim D, Bach DH, Fan YH, Luu TT, Hong JY, Park HJ and Lee SK: AXL degradation in combination with EGFR-TKI can delay and overcome acquired resistance in human non-small cell lung cancer cells. Cell Death Dis 10: 361, 2019.

14. Wang W, Wang H, Lu P, Yu Z, Xu C, Zhuang W and Song Z: Crizotinib with or without an EGFR-TKI in treating EGFR-mutant NSCLC patients with acquired MET amplification after failure of EGFR-TKI therapy: A multicenter retrospective study. J Transl Med 17: 52, 2019.

15. Zhou H, Zeng C, Wang LY, Xie H, Zhou J, Diao P, Yao WX, Zhao X and Wei Y: Chemotherapy with or without gefitinib in patients with advanced non-small-cell lung cancer: A meta-analysis of 6,844 patients. Chin Med J (Engl) 126: 3348-3355, 2013.

16. Fang H, Lin RY, Sun MX, Wang Q, Zhao YL, Yu JL, Tian Y and Wang XY: Efficacy and survival-associated factors with gefitinib combined with cisplatin and gemcitabine for advanced non-small cell lung cancer. Asian Pac J Cancer Prev 15: 10967-10970, 2014.

17. Lee S, Joo J, Kwak M, Sohn K and Chon S: Role of chemotherapy with epidermal growth factor receptor-tyrosine kinase inhibitor (EGFR-TKI) rechallenge in small cell transformation after EGFR-TKI failure: A case report. Onco Targets Ther 11: 3943-3947, 2018.

18. Ding T, Zhou F, Chen X, Zhang S, Liu Y, Sun H, Ren S, Li X, Zhao C, Wang $\mathrm{H}$ and Zhou C: Continuation of gefitinib plus chemotherapy prolongs progression-free survival in advanced non-small cell lung cancer patients who get acquired resistance to gefitinib without T790M mutations. J Thorac Dis 9: 2923-2934, 2017.

19. Anderson NG, Ahmad T, Chan K, Dobson R and Bundred NJ: ZD1839 (Iressa), a novel epidermal growth factor receptor (EGFR) tyrosine kinase inhibitor, potently inhibits the growth of EGFR-positive cancer cell lines with or without erbB2 overexpression. Int J Cancer 94: 774-782, 2001.

20. Anido J, Matar P, Albanell J, Guzmán M, Rojo F, Arribas J, Averbuch S and Baselga J: ZD1839, a specific epidermal growth factor receptor (EGFR) tyrosine kinase inhibitor, induces the formation of inactive EGFR/HER2 and EGFR/HER3 heterodimers and prevents heregulin signaling in HER2-overexpressing breast cancer cells. Clin Cancer Res 9: 1274-1283, 2003.

21. Roberts JJ and Friedlos F: Quantitative estimation of cisplatin-induced DNA interstrand cross-links and their repair in mammalian cells: Relationship to toxicity. Pharmacol Ther 34: 215-246, 1987. 
22. Dijt FJ, Fichtinger-Schepman AM, Berends F and Reedijk J: Formation and repair of cisplatin-induced adducts to DNA in cultured normal and repair-deficient human fibroblasts. Cancer Res 48: 6058-6062, 1988

23. Pera MF, Jr., Rawlings CJ and Roberts JJ: The role of DNA repair in the recovery of human cells from cisplatin toxicity. Chem Biol Interact 37: 245-261, 1981.

24. Chu G and Berg P: DNA cross-linked by cisplatin: A new probe for the DNA repair defect in xeroderma pigmentosum. Mol Biol Med 4: 277-290, 1987

25. Shao CJ, Fu J, Shi HL, Mu YG and Chen ZP: Activities of DNA-PK and Ku86, but not Ku70, may predict sensitivity to cisplatin in human gliomas. J Neurooncol 89: 27-35, 2008.

26. Ryu JS, Memon A and Lee SK: ERCC1 and personalized medicine in lung cancer. Ann Transl Med 2: 32, 2014

27. Wang LR, He LJ, Wang Y, Li YY, Lou Y, Zhang GB, Li Y and Chen J: Correlation between BRCA1 and TopBP1 protein expression and clinical outcome of non-small cell lung cancer treated with platinum-based chemotherapy. Cancer Chemother Pharmacol 76: 163-170, 2015

28. Wang SC and Hung MC: Nuclear translocation of the epidermal growth factor receptor family membrane tyrosine kinase receptors. Clin Cancer Res 15: 6484-6489, 2009.

29. Rodemann HP, Dittmann K and Toulany M: Radiation-induced EGFR-signaling and control of DNA-damage repair. Int J Radiat Biol 83: 781-791, 2007.

30. Wang SC, Nakajima Y, Yu YL, Xia W, Chen CT, Yang CC, McIntush EW, Li LY, Hawke DH, Kobayashi R and Hung MC: Tyrosine phosphorylation controls PCNA function through protein stability. Nat Cell Biol 8: 1359-1368, 2006.

31. Das AK, Chen BP, Story MD, Sato M, Minna JD, Chen DJ and Nirodi CS: Somatic mutations in the tyrosine kinase domain of epidermal growth factor receptor (EGFR) abrogate EGFR-mediated radioprotection in non-small cell lung carcinoma. Cancer Res 67: 5267-5274, 2007.

32. Liccardi G, Hartley JA and Hochhauser D: EGFR nuclear translocation modulates DNA repair following cisplatin and ionizing radiation treatment. Cancer Res 71: 1103-1114, 2011.

33. Chou TC: Drug combination studies and their synergy quantification using the Chou-Talalay method. Cancer Res 70: 440-446, 2010.

34. Lee GY, Kenny PA, Lee EH and Bissell MJ: Three-dimensional culture models of normal and malignant breast epithelial cells. Nat Methods 4: 359-365, 2007.

35. Westover D, Zugazagoitia J, Cho BC, Lovly CM and Paz-Ares L: Mechanisms of acquired resistance to first- and second-generation EGFR tyrosine kinase inhibitors. Ann Oncol 29 (Suppl 1) i10-i19, 2018

36. Zhang Q,Kanterewicz B, Shoemaker S, Hu Q, Liu S, Atwood K and Hershberger P: Differential response to $1 \alpha, 25$-dihydroxyvitamin D3 $(1 \alpha, 25(\mathrm{OH}) 2 \mathrm{D} 3)$ in non-small cell lung cancer cells with distinct oncogene mutations. J Steroid Biochem Mol Biol 136: 264-270, 2013

37. Takezawa K, Okamoto I, Yonesaka K, Hatashita E, Yamada Y, Fukuoka $M$ and Nakagawa K: Sorafenib inhibits non-small cell lung cancer cell growth by targeting B-RAF in KRAS wild-type cells and C-RAF in KRAS mutant cells. Cancer Res 69: 6515-6521, 2009.

38. Li T, Ling YH, Goldman ID and Perez-Soler R Schedule-dependent cytotoxic synergism of pemetrexed and erlotinib in human non-small cell lung cancer cells. Clin Cancer Res 13: 3413-3422, 2007.

39. Zhang W, Peyton M, Xie Y, Soh J, Minna JD, Gazdar AF and Frenkel EP: Histone deacetylase inhibitor romidepsin enhances anti-tumor effect of erlotinib in non-small cell lung cancer (NSCLC) cell lines. J Thorac Oncol 4: 161-166, 2009.

40. Van Schaeybroeck S, Kyula J, Kelly DM, Karaiskou-McCaul A, Stokesberry SA, Van Cutsem E, Longley DB and Johnston PG: Chemotherapy-induced epidermal growth factor receptor activation determines response to combined gefitinib/chemotherapy treatment in non-small cell lung cancer cells. Mol Cancer Ther 5: $1154-1165,2006$.

41. Kim GW, Song JS, Choi CM, Rho JK, Kim SY, Jang SJ, Park YS, Chun SM, Kim WS, Lee JS, et al: Multiple resistant factors in lung cancer with primary resistance to EGFR-TK inhibitors confer poor survival. Lung Cancer 88: 139-146, 2015.

42. Karachaliou N, Rosell R, Molina MA and Viteri S: Predicting resistance by selection of signaling pathways. Transl Lung Cancer Res 3: 107-115, 2014.
43. Lynch TJ, Bell DW, Sordella R, Gurubhagavatula S, Okimoto RA, Brannigan BW, Harris PL, Haserlat SM, Supko JG, Haluska FG, et al: Activating mutations in the epidermal growth factor receptor underlying responsiveness of non-small-cell lung cancer to gefitinib. N Engl J Med 350: 2129-2139, 2004.

44. Denis MG, Vallée A and Théoleyre S: EGFR T790M resistance mutation in non small-cell lung carcinoma. Clin Chim Acta 444: $81-85,2015$

45. Sordella R, Bell DW, Haber DA and Settleman J: Gefitinib-sensitizing EGFR mutations in lung cancer activate anti-apoptotic pathways. Science 305: 1163-1167, 2004.

46. Vitale MG, Riccardi F, Mocerino C, Barbato C, Monaco R, Galloro P, Gagliardi N and Cartenì G: Erlotinib-induced complete response in a patient with epidermal growth factor receptor wild-type lung adenocarcinoma after chemotherapy failure: A case report. J Med Case Rep 8: 102, 2014.

47. Tsai CM, Chen JT, Stewart DJ, Chiu CH, Lai CL, Hsiao SY, Chen YM and Chang KT: Antagonism between gefitinib and cisplatin in non-small cell lung cancer cells: Why randomized trials failed? J Thorac Oncol 6: 559-568, 2011.

48. Laurila $\mathrm{N}$ and Koivunen JP: EGFR inhibitor and chemotherapy combinations for acquired TKI resistance in EGFR-mutant NSCLC models. Med Oncol 32: 205, 2015.

49. Zhang Y, Yang H, Yang X, Deng Q, Zhao M, Xu X and He J: Erlotinib with pemetrexed/cisplatin for patients with EGFR wild-type lung adenocarcinoma with brain metastases. Mol Clin Oncol 2: 449-453, 2014.

50. Pao W, Wang TY, Riely GJ, Miller VA, Pan Q, Ladanyi M, Zakowski MF, Heelan RT, Kris MG and Varmus HE: KRAS mutations and primary resistance of lung adenocarcinomas to gefitinib or erlotinib. PLoS Med 2: e17, 2005.

51. Eberhard DA, Johnson BE, Amler LC, Goddard AD, Heldens SL, Herbst RS, Ince WL, Jänne PA, Januario T, Johnson DH, et al: Mutations in the epidermal growth factor receptor and in KRAS are predictive and prognostic indicators in patients with non-small-cell lung cancer treated with chemotherapy alone and in combination with erlotinib. J Clin Oncol 23: 5900-5909, 2005.

52. Rosetti M,Zoli W, Tesei A,Ulivi P,FabbriF, Vannini I, Brigliadori G, Granato AM, Amadori D and Silvestrini R: Iressa strengthens the cytotoxic effect of docetaxel in NSCLC models that harbor specific molecular characteristics. J Cell Physiol 212: 710-716, 2007.

53. Mok TSK, Kim SW, Wu YL, Nakagawa K, Yang JJ, Ahn MJ, Wang J, Yang JC, Lu Y, Atagi S, et al: Gefitinib plus chemotherapy versus chemotherapy in epidermal growth factor receptor mutation-positive non-small-cell lung cancer resistant to first-line gefitinib (IMPRESS): Overall survival and biomarker analyses. J Clin Oncol 35: 4027-4034, 2017.

54. Melisi D, Troiani T, Damiano V, Tortora G and Ciardiello F: Therapeutic integration of signal transduction targeting agents and conventional anti-cancer treatments. Endocr Relat Cancer 11: 51-68, 2004.

55. Fujiwara K, Kiura K, Gemba K, Ogata Y, Hotta K, Kishino D, Tabata M, Ueoka H and Tanimoto M: Gefitinib ('Iressa',ZD1839) may restore chemosensitivity in NSCLC patients? Anticancer Res 25: 547-549, 2005

56. Dai Q, Ling YH, Lia M, Zou YY, Kroog G, Iwata KK and Perez-Soler R: Enhanced sensitivity to the HER1/epidermal growth factor receptor tyrosine kinase inhibitor erlotinib hydrochloride in chemotherapy-resistant tumor cell lines. Clin Cancer Res 11: 1572-1578, 2005.

57. Hilger RA, Scheulen ME and Strumberg D: The Ras-Raf-MEK-ERK pathway in the treatment of cancer. Onkologie 25: 511-518, 2002.

58. Cheng GZ, Park S, Shu S, He L, Kong W, Zhang W, Yuan Z, Wang LH and Cheng JQ: Advances of AKT pathway in human oncogenesis and as a target for anti-cancer drug discovery. Curr Cancer Drug Targets 8: 2-6, 2008.

59. Sharrard RM and Maitland NJ: Regulation of protein kinase B activity by PTEN and SHIP2 in human prostate-derived cell lines. Cell Signal 19: 129-138, 2007.

60. Kokubo Y, Gemma A, Noro R, Seike M, Kataoka K, Matsuda K, Okano T, Minegishi Y, Yoshimura A, Shibuya M and Kudoh S: Reduction of PTEN protein and loss of epidermal growth factor receptor gene mutation in lung cancer with natural resistance to gefitinib (IRESSA). Br J Cancer 92: 1711-1719, 2005.

61. Albitar L, Carter MB, Davies S and Leslie KK: Consequences of the loss of p53, RB1, and PTEN: Relationship to gefitinib resistance in endometrial cancer. Gynecol Oncol 106: 94-104, 2007. 
62. Yamamoto C, Basaki Y, Kawahara A, Nakashima K, Kage M, Izumi $\mathrm{H}$, Kohno $\mathrm{K}$, Uramoto $\mathrm{H}$, Yasumoto K, Kuwano $\mathrm{M}$ and Ono M: Loss of PTEN expression by blocking nuclear translocation of EGR1 in gefitinib-resistant lung cancer cells harboring epidermal growth factor receptor-activating mutations. Cancer Res 70: 8715-8725, 2010.

63. Friedmann BJ, Caplin M, Savic B, Shah T, Lord CJ, Ashworth A, Hartley JA and Hochhauser D: Interaction of the epidermal growth factor receptor and the DNA-dependent protein kinase pathway following gefitinib treatment. Mol Cancer Ther 5: 209-218, 2006.

64. Friedmann B, Caplin M,Hartley JA and Hochhauser D: Modulation of DNA repair in vitro after treatment with chemotherapeutic agents by the epidermal growth factor receptor inhibitor gefitinib (ZD1839). Clin Cancer Res 10: 6476-6486, 2004.

65. Dittmann K, Mayer C, Fehrenbacher B, Schaller M, Raju U, Milas L, Chen DJ, Kehlbach R and Rodemann HP: Radiation-induced epidermal growth factor receptor nuclear import is linked to activation of DNA-dependent protein kinase. J Biol Chem 280: 31182-31189, 2005.
66. Dittmann K, Mayer C and Rodemann HP: Inhibition of radiation-induced EGFR nuclear import by C225 (Cetuximab) suppresses DNA-PK activity. Radiother Oncol 76: 157-161, 2005.

67. Dittmann K, Mayer C, Czemmel S, Huber SM and Rodemann HP: New roles for nuclear EGFR in regulating the stability and translation of mRNAs associated with VEGF signaling. PLoS One 12: e0189087, 2017.

68. Sok JC, Coppelli FM, Thomas SM, Lango MN, Xi S, Hunt JL, Freilino ML, Graner MW, Wikstrand CJ, Bigner DD, et al: Mutant epidermal growth factor receptor (EGFRvIII) contributes to head and neck cancer growth and resistance to EGFR targeting. Clin Cancer Res 12: 5064-5073, 2006.

This work is licensed under a Creative Commons Attribution-NonCommercial-NoDerivatives 4.0 International (CC BY-NC-ND 4.0) License. 